\title{
Effect of trimmed asparagus by-products supplementation in broiler diets on performance, nutrients digestibility, gut ecology, and functional meat production
}

\author{
Manatsanun Nopparatmaitree ${ }^{1}$ (iD), Marisa Nava ${ }^{1}$, Verachai Chumsangchotisakun ${ }^{1}$, Pornpan Saenphoom ${ }^{1}$, \\ Soranot Chotnipat ${ }^{1}$ and Warangkana Kitpipit ${ }^{2,3,4}$ (i)
}

1. Faculty of Animal Science and Agricultural Technology, Silpakorn University, Phetchaburi IT Campus, Cha-Am, Phetchaburi, 76120, Thailand; 2. Akkhraratchakumari Veterinary College, Walailak University, Nakhon Si Thammarat, 80160, Thailand; 3. One Health Research Center, Walailak University, Nakhon Si Thammarat, 80160, Thailand; 4. Food Technology and Innovation Research Center of Excellent, Walailak University, Nakhon Si Thammarat, 80160, Thailand.

Corresponding author: Manatsanun Nopparatmaitree, e-mail: nopparatmaitree_m@silpakorn.edu Co-author: MNa: mooaom_zajung@hotmail.com,VC: ekk_4268@hotmail.com,

PS: saenphoom_p@silpakorn.edu, SC: chotnipat_s@silpakorn.edu,WK: warangkana.ki@wu.ac.th Received: 14-09-2021, Accepted: 28-12-2021, Published online: 26-01-2022

doi: www.doi.org/10.14202/vetworld.2022.147-161 How to cite this article: Nopparatmaitree $M, N a v a ~ M$, Chumsangchotisakun V, Saenphoom P, Chotnipat S, Kitpipit W (2022) Effect of trimmed asparagus by-products supplementation in broiler diets on performance, nutrients digestibility, gut ecology, and functional meat production, Veterinary World, 15(1): 147-161.

\begin{abstract}
Background and Aim: Trimmed asparagus by-products (TABP) is the resultant waste from asparagus possessing. TABP has fructans, such as inulins and fructooligosaccharide, which can be utilized as an alternative prebiotic. This study was conducted to examine the effect of TABP dietary supplementation on the productive performance, nutrient digestibility, gut microbiota, volatile fatty acid (VFA) content, small-intestine histology, and meat quality of broilers.

Materials and Methods: A total of 320 1-day-old broiler chicks (Ross $308^{\circledR}$ ) were raised under ambient temperature and assigned through a completely randomized design to one of four dietary treatments, with four replicates per treatment. The dietary treatments comprised corn-soybean basal diet supplemented with 0 (control), 10, 30, or $50 \mathrm{~g} / \mathrm{kg}$ TABP. All birds were provided drinking water and feed ad libitum to meet the standard nutritional requirements of National Research Council for broiler chickens.

Results: TABP supplementation to the broilers significantly increased the apparent ether extract, crude fiber, and gross energy digestibility $(\mathrm{p}<0.05)$. TABP supplementation significantly increased lactic bacteria and Enterococcus spp. numbers as well as acetic, propionic, butyric, and total VFA levels ( $<<0.01$ ); on the other hand, it also significantly decreased Salmonella spp. and Escherichia coli contents in the cecum compared with the control group $(\mathrm{p}<0.01)$. Moreover, TABP supplementation increased villus height in the duodenum and jejunum $(\mathrm{p}<0.01)$, cryptal depth in the jejunum and ileum $(\mathrm{p}<0.01)$, and villus surface areas in the duodenum, jejunum, and ileum $(\mathrm{p}<0.01)$. Overall, $0-35$ day TABP supplementation significantly increased the feed intake $(p<0.01)$ and average daily gain of broilers $(p<0.05)$, but not significantly affected the viability, productive index, and economic benefit return $(\mathrm{p}>0.05)$. The carcass characteristics, $\mathrm{pH}$, color, and water holding capacity of the chicken meat between groups were not significantly different $(p>0.05)$. All levels of TABP supplementation appeared to be a feasible means of producing broilers with the lower serum low-density lipoprotein cholesterol and triglyceride levels as well as atherogenic indices of serum compared with the control $(p<0.05)$. Cholesterol contents and palmitic acid, oleic acid, saturated fatty acids, and Monounsaturated fatty acids levels decreased with an increase of TABP supplementation $(\mathrm{p}<0.05)$. Furthermore, TABP supplementation decreased atherogenic index (AI) and thrombogenicity index (TI) of meat $(\mathrm{p}<0.05)$.
\end{abstract}

Conclusion: Supplementation of $30 \mathrm{~g} / \mathrm{kg}$ TABP in broiler diet could enhance broiler performance and provide chicken meat with beneficial properties, with decreased AI and TI resulted from altered cholesterol and fatty acid profiles.

Keywords: asparagus by-products, broiler, functional feed, functional meat, prebiotic.

\section{Introduction}

Diets could influence various functions of the body and improve the health status of livestock. Many

Copyright: Nopparatmaitree, et al. Open Access. This article is distributed under the terms of the Creative Commons Attribution 4.0 International License (http://creativecommons.org/licenses/ by/4.0/), which permits unrestricted use, distribution, and reproduction in any medium, provided you give appropriate credit to the original author(s) and the source, provide a link to the Creative Commons license, and indicate if changes were made. The Creative Commons Public Domain Dedication waiver (http:// creativecommons.org/publicdomain/zero/1.0/) applies to the data made available in this article, unless otherwise stated. nutrient groups are classified as functional feeds, including probiotics, prebiotics, synbiotics, and phytobiotics [1]. After 2006, the European Union announced the need to eliminate antibiotics in broiler feed to reduce the presence of antibiotic residues in meat products, which could affect drug resistance and consumer health [2]. This initiative resulted in the use of a popular functional feed in the broiler production industry and reductions in antibiotic resistance. Moreover, natural products with functional properties have been used in animal husbandry for growth and other indirect 
benefits. In addition, The World Health Organization predicted that cardiovascular disease will become the leading cause of death in 2030 and affect approximately 23.6 million people worldwide [3]. Functional food plays an important role in human life and can potentially promote optimal health status and reduce disease risk. Therefore, raising broiler on functional diets to produce functional broiler meat products is especially intriguing in the context of health-conscious dietary trends.

Agricultural countries generate a large amount of agricultural waste, which impacts the environment due to incineration, landfill, and allowing agricultural waste to rot and decompose naturally. As a result, proper waste disposal is a major challenge. Bio-circular-green economies strongly support research into high-potential, low-cost raw materials derived from agricultural waste for functional feeds. Asparagus is an attractive functional feed source because it is a popular Thai economic crop for domestic consumption and foreign export. Trimmed asparagus by-products (TABPs), which refer to asparagus parts that cannot be sold or processed during the quality selection phase of vegetable production, make up approximately $30-40 \%$ of the total harvest [4]. Asparagus root contains fructans and comprises approximately $25 \%$ of the fresh weight of the plant [5]. The amount of fructans in the edible portion of asparagus varies depending on the variety and could range from $0.5 \%$ to $2 \%$ (dry weight); asparagus also has high fiber contents, a distinct flavor, and several phytochemicals (e.g., vitamins, fructans, flavonoids, cinnamic acids, and saponins). TABP is an interesting material for use as a functional broiler feed due to its high fructan (e.g., inulin and fructooligosaccharide [FOS]) contents [6]. Fructans are very common prebiotics with structures consisting of short-chain and non-digestible carbohydrates [7]. Inulin and FOS are essential for beneficial microorganisms to survive in the digestive tract. The beneficial microorganism in the gut system can thrive with the assistance of inulin and FOS because they can be used as substrates for the survival and multiplication of probiotics in the lower gut region, where they act as symbiotic bacteria [8]. The previous research on broiler chickens showed that inulin and FOS supplementation can stimulate the gut fermentation of useful bacteria, such as bifidobacteria and lactobacilli, and limit the colonization of infective bacteria, such as Salmonella spp. and Escherichia coli [9]. Prebiotics can be fermented in the intestine by health-promoting bacteria to yield lactic acid and short-chain fatty acids (SCFAs) [10]. SCFAs are important energy sources in the intestine. Butyrate is a major SCFA metabolized by epithelial cells to provide energy for mucosal epithelial growth, improve the intestinal mucosal structure, and positively modify the gut microbiota [11]. Inulin and FOS can enhance the innate and acquired immune response [12], nutrient digestibility efficiency, and growth performance [13].
Furthermore, they can decrease serum cholesterol and improve the quality of chicken meat by stimulating probiotic fermentation to produce SCFAs [14] and bile salt hydrolase (BSH) during the hypocholesterolemic process [15]. The BSH can lower total cholesterol in the body [16]. The previous study showed that prebiotics and probiotics can decrease low-density lipoprotein (LDL) cholesterol and triglyceride levels [16], while increase high-density lipoprotein (HDL) cholesterol, and modify lipid compositions [17].

The researches on asparagus waste as prebiotic supplementation in livestock diets are limited. This study aimed to investigate the effect of TABP supplementation of broiler diets on the apparent nutrient digestibility, microbial ecology, small-intestine histology, production performance, carcass characteristics, and meat quality and fatty acid composition. The results could contribute to the current understanding of approaches to optimize digestive functions, nutrient utilization, and meat production by supplementing broiler diets with asparagus waste.

\section{Materials and Methods}

\section{Ethical approval}

The Animal Care Protocol Management and Review Committee of the Faculty of Animal Science and Agricultural Technology, Silpakorn University, approved the experimental protocol for this study (record no. ASAT SU0101/2562).

\section{Study period and location}

This study was conducted from October to December 2019 (for animal husbandry) and from January to March 2020 (for laboratory) at Agricultural Technology Training and Transfer Center, Faculty of Animal Science and Agricultural Technology, Silpakorn University, Phetchaburi IT campus.

\section{TABP sample}

TABP was collected from Hup-krapong (12.7775, 99.9096), Cha Am district, Phetchaburi Province, as part of The Royal Project of His Majesty the King of Thailand. TABP $(90 \%$ root stock, $10 \%$ spear) were sliced and spread on a plastic sheet for 3 days before being oven-dried at $60^{\circ} \mathrm{C}$ for 3 days. Dried TABP sample was ground to a uniform size of $2 \mathrm{~mm}$ by pulverizing machine (RT-34, Chyun Tseh Industrial Co., Ltd., Republic of China). Furthermore, chemical composition of TABP was analyzed according to Association of Official Analytical Chemists (AOAC) [18], as well as FOS content was determined using thin-layer chromatography according to Reiffová and Nemcová's [19]. Nutrient composition analyzed that TABP contains $86.80 \%$ dry mater, $18.50 \%$ crude protein, $0.61 \%$ ether extract, $37.62 \%$ crude fiber, $9.23 \%$ crude ash, $2175.23 \mathrm{kacl} / \mathrm{kg}, 0.10 \%$ calcium, $0.66 \%$ phosphorus, and $1.84 \%$ FOS.

\section{Experimental design, diets, and birds}

A total of 320 (160 male and 160 female) 1-dayold Ross 308 broiler chicks with an average body weight 
of $40.46 \pm 1.25 \mathrm{~g}$ were obtained from a commercial hatchery (Farmmach Hatchery, Cha Am, Phetchaburi, Thailand). The birds were assigned through a completely randomized design to one of four treatments with four replicates ( $\mathrm{n}=20$ birds). The treatments applied were T1: Ration without TABP, T2: Ration $+10 \mathrm{~g} / \mathrm{kg}$ TABP powder; T3: Ration $+30 \mathrm{~g} / \mathrm{kg}$ TABP powder, and T4: Ration $+50 \mathrm{~g} / \mathrm{kg}$ TABP powder. The birds were housed in floor pens with new rice hulls in an open-sided house system. Newly hatched birds were brooded at $35^{\circ} \mathrm{C}$ and $60 \% \mathrm{RH}$ for 10 days and then exposed to ambient temperature until the end of the experiments at 35 days. The broilers were vaccinated against Marek's disease at the hatchery, Newcastle disease and infectious bronchitis at the farm on day 7, and Gumboro disease on day 14. All birds were offered ad libitum access to feed and water. The nutrient content of the diets used in the study corresponded to the needs of broilers raised in tropical climates. Throughout the experiments, the birds were fed mash diets for starters (1-21 days; $23 \% \mathrm{CP}, 3200 \mathrm{kcal} / \mathrm{kg}$ ) and growers/finishers (21-35 days; $20 \% \mathrm{CP}, 3200 \mathrm{kcal} / \mathrm{kg})$ according to the National Research Council (NRC) [20] as shown in Table-1.

\section{Apparent nutrient digestibility}

The apparent digestibility of nutrients was calculated using the indicator method of Fenton and Fenton [21]. Thirty-two 1-day-old chicks were randomly placed in metabolic cages (two birds/cage) for feces collection to study digestibility. All birds in each cage had free access to water and feed containing $0.3 \%$ chromium oxide $\left(\mathrm{Cr}_{2} \mathrm{O}_{3}\right)$ from days 0 to 18 to adopt to the diets and metabolic cages. Feces collection was then performed over 3 days (days 19-21). Feathers and other contamination were carefully removed, and the excreta collected in each cage with $3 \% \mathrm{H}_{2} \mathrm{SO}_{4}$ over 2 days was pooled and stored at $-20^{\circ} \mathrm{C}$. Excreta samples were thawed and dried at $60^{\circ} \mathrm{C}$ for $48 \mathrm{~h}$, ground through a $0.5 \mathrm{~mm}$ sieve, and then stored in airtight plastic containers for analysis according to Mountzouris et al. [22] and Ghayour-Najafabadi et al. [23]. Feed and feces samples were analyzed in the laboratory for dry matter, organic matter, crude protein, crude fiber, ether extract, gross energy, and $\mathrm{Cr}_{2} \mathrm{O}_{3}$ contents according to the method of AOAC [18]. Apparent dry matter and nutrient digestibility were calculated according to Zewdie [24].

\section{Cecal microbiota, volatile fatty acid (VFA) contents, and small-intestine histomorphology}

On day 21, four birds (i.e., two males and two females) from each pen with the closest weight to the mean body weight were sacrificed by cervical dislocation. Cecum contents were sampled to count the number of microorganisms and then packed in ice buckets for laboratory analysis. Exactly $1.5 \mathrm{~g}$ of cecum content samples was decomposed in sterile water $(1: 1 \mathrm{~g} / \mathrm{vol})$ in a screw-capped tube and sampled at $-20^{\circ} \mathrm{C}$ for VFA analysis according to Khattak et al. [25]. Duodenal, jejunal, and ileal samples measuring approximately $2.5 \mathrm{~cm}$ in length were cut and

Table-1: Ingredient composition and nutritive value of the experimental diet.

\begin{tabular}{|c|c|c|c|c|c|c|c|c|}
\hline \multirow[t]{2}{*}{ Experimental diet* } & \multicolumn{4}{|c|}{ Starter diet (0-21 days) } & \multicolumn{4}{|c|}{ Finisher diet (22-35 days) } \\
\hline & T1 & T2 & T3 & T4 & $\mathbf{T 1}$ & T2 & T3 & T4 \\
\hline \multicolumn{9}{|l|}{ Ingredient composition (\%) } \\
\hline Corn & 49.50 & 48.50 & 49.50 & 49.50 & 46.92 & 46.92 & 46.92 & 46.92 \\
\hline Soybean meal (44\%CP) & 36.50 & 36.32 & 35.96 & 35.60 & 30.90 & 30.72 & 30.36 & 30.00 \\
\hline $\mathrm{TABP}^{1}$ & - & 1.00 & 3.00 & 5.00 & - & 1.00 & 3.00 & 5.00 \\
\hline Defatted rice bran & 8.00 & 7.18 & 5.54 & 3.90 & 12.50 & 11.68 & 10.04 & 8.4 \\
\hline Rice bran oil & 1.70 & 1.70 & 1.70 & 1.70 & 5.56 & 5.56 & 5.56 & 5.56 \\
\hline Limestone $\left(\mathrm{CaCO}_{3}\right)$ & 1.35 & 1.35 & 1.35 & 1.35 & 1.20 & 1.20 & 1.20 & 1.20 \\
\hline $\operatorname{DCP}(18 \% \mathrm{P})$ & 2.10 & 2.10 & 2.10 & 2.10 & 1.90 & 1.90 & 1.90 & 1.90 \\
\hline Choline Chloride-L & 0.03 & 0.03 & 0.03 & 0.03 & 0.03 & 0.03 & 0.03 & 0.03 \\
\hline $\mathrm{NaCl}$ & 0.14 & 0.14 & 0.14 & 0.14 & 0.23 & 0.23 & 0.23 & 0.23 \\
\hline DL-Methionine (99\%) & 0.34 & 0.34 & 0.34 & 0.34 & 0.28 & 0.28 & 0.28 & 0.28 \\
\hline L-lysine $(98.5 \%)$ & - & - & - & - & 0.22 & 0.22 & 0.22 & 0.22 \\
\hline L-Threonine $(98.5 \%)$ & 0.15 & 0.15 & 0.15 & 0.15 & 0.06 & 0.06 & 0.06 & 0.06 \\
\hline Premix $x^{2}$ & 0.20 & 0.20 & 0.20 & 0.20 & 0.02 & 0.02 & 0.02 & 0.02 \\
\hline Total & 100.00 & 100.00 & 100.00 & 100.00 & 100.00 & 100.00 & 100.00 & 100.00 \\
\hline \multicolumn{9}{|c|}{ Nutritive value from laboratory analysis (\%) } \\
\hline Dry matter & 90.35 & 90.31 & 91.02 & 90.67 & 91.13 & 90.76 & 90.87 & 90.49 \\
\hline Crude protein & 23.56 & 23.91 & 23.71 & 13.57 & 20.49 & 20.36 & 20.41 & 20.33 \\
\hline Ether extract & 5.39 & 5.23 & 5.60 & 5.00 & 5.51 & 5.30 & 5.52 & 5.63 \\
\hline Crude fiber & 4.26 & 4.19 & 4.51 & 4.49 & 3.54 & 3.79 & 4.87 & 4.90 \\
\hline Ash & 8.11 & 7.93 & 7.36 & 6.35 & 6.82 & 7.10 & 6.61 & 7.31 \\
\hline Gross energy $(\mathrm{Kcal} / \mathrm{kg})$ & 4079.30 & 4033.60 & 4012.30 & 4073.90 & 4089.60 & 4069.90 & 4148.90 & 4082.00 \\
\hline
\end{tabular}

*T1: Ration without TABP, T2: Ration+10 g/kg TABP powder; T3: Ration+30 g/kg TABP powder, and T4:

Ration $+50 \mathrm{~g} / \mathrm{kg}$ TABP powder. ${ }^{1} \mathrm{TABP}=$ Trimmed asparagus by-products. ${ }^{2}$ Each one kilogram of vitamin-mineral premix contained 20.02 MIU of retinal palmitate, 9.10 MIU of cholecalciferol, $136.50 \mathrm{~g}$ of DL-3-tocopheryl acetate, $5.46 \mathrm{~g}$ of phylloquinone, $5.46 \mathrm{~g}$ of thiamine, $14.56 \mathrm{~g}$ of riboflavin, $27.30 \mathrm{~g}$ of Ca-D-pantothenate, $7.28 \mathrm{~g}$ of pyridoxine, $109.20 \mathrm{~g}$ of niacin, $3.64 \mathrm{~g}$ of folic acid, $29.12 \mathrm{mg}$ of cobalamin, $237.00 \mathrm{mg}$ of D-biotin, $120 \mathrm{~g}$ of manganese, $3.00 \mathrm{~g}$ of selenium, $1000 \mathrm{mg}$ of zinc, $160.00 \mathrm{mg}$ of copper, $400.00 \mathrm{mg}$ of ferrous, $12.50 \mathrm{~g}$ of iodine. TABP=Trimmed asparagus by-products 
rinsed with saline solution to remove the digesta, according to Shang et al. [12]. The samples were fixed in 10\% neutral-buffered formalin, according to Gava et al. [26]. The numbers of lactic acid bacteria, Enterococcus, E. coli, and Salmonella in $1 \mathrm{~g}$ of cecal fluid samples were counted. The fluid samples were then diluted ten-fold using a culture technique with selective media De Man, Rogosa and Sharpe agar (Difco, USA) $+0.02 \% \mathrm{NaH}_{3}+0.05 \%$ L-cystine hydrochloride monohydrate, Eosin methylene blue agar (HiMedia, India), and m-Enterococcus agar (HiMedia) according to McDonald et al. [27], Horn et al. [28], and Schillinger and Holzapfel [29]. The number of microorganisms was transformed using the base $10 \log$ algorithm [30].

VFA concentrations were determined from the cecum contents collected from each experimental group. Sample preparation for VFA content determination was performed according to Walugembe et al. [31]. The sample solution was injected into a gas chromatograph (HP 5890 Series II GC; Agilent J\&W; $30 \mathrm{~m} \times 0.535 \mathrm{~mm} \times 1.00 \mathrm{micron}$ HP-FFAP column) to detect acetic, propionic, and butyric acids; 4-methylvaleric acid (Alfa Aesar, United Kingdom) was used as the internal standard, and a flame-ionization detector was used for measurement. The VFA composition of the samples was then compared with the standard solution according to Khattak et al. [25].

For histological studies, samples were dehydrated, cleared, and embedded in paraffin in the laboratory using standard histological procedures. Six-micrometer-thick sections were cut, placed on glass slides, stained with hematoxylin and eosin, and examined under a light microscope, according to Wang et al. [2]. The histomorphology of the small intestine was assessed using an Olympus BX 50 optical microscope at $20 \times$ magnification and analyzed using the Motic Images 2.0 multi-language program [32]. Samples of 10 villi per slide were evaluated to determine villus height, width, and cryptal depth, according to Wang et al. [2]. The surface area of a villus was calculated $\{(\mathbb{\Phi}) \times$ Villus width/2) $\times$ Villus height)\} according to Sakamoto et al. [33].

\section{Productive performance and economic returns}

Chickens were reared for 35 days and observed daily. The body weight, feed intake, and mortality of the birds were recorded on days 21 (i.e., the end of the starter phase) and 35 (i.e., the end of the grower/finisher phase). Average daily feed intake, average body weight gain (BWG), average daily gain (ADG), feed conversion ratio (FCR; feed/gain), and viability were calculated as indicators of production performance following the formulas described by Marcu et al. [34]. Production index (PI) was calculated following the formula of Barbosa et al. [35]. Economic return indicators, such as feed cost per gain (FCG), salable bird return (SBR), net profit per bird (NPR), and return on investment (ROI) were calculated according to the formulas of Ojediran et al. [36].
- $\quad \mathrm{PI}=(\mathrm{ADG}(\mathrm{kg}) \times$ livability $/ \mathrm{FCR}) \times 100$

- $\quad \mathrm{FCG}=(\mathrm{FCR} \times$ feed $\cos \mathrm{x} \times \mathrm{BWG})$

- $\quad \mathrm{SBR}=($ Price of live chicken $\times$ Body weigth $)$

- $\quad \mathrm{NPR}=(\mathrm{SBR}-\mathrm{FCG})$

- $\quad \mathrm{ROI}=(\mathrm{NPR} / \mathrm{FCG}) \times 100$.

Hematology, carcass, meat quality, and meat fatty acid composition

The blood samples used in this study were collected from 35-day-old broilers; two males and two females per pen were used. Blood samples were collected from the wing vein into tubes with EDTAK3 for plasma sampling according to Seifi et al. [37]. Blood was also sampled into non-EDTAK3 tubes. The serum in these samples was harvested and stored at $-20^{\circ} \mathrm{C}$ for biochemical analysis according to Dev et al. [38]. Hematocrit, red blood cell (RBC), white blood cell (WBC), heterophils $(\mathrm{H})$, and lymphocytes (L) were determined, and the $\mathrm{H} / \mathrm{L}$ ratio was calculated according to Reisinger et al. [39]. Serum cholesterol and triglyceride levels were determined using an automatic hematology testing machine (Advia 120, Bayer, Tarrytown, NY, USA) through an enzymatic colorimetric method (i.e., the CHOD-PAP method) according to Zhao et al. [13]. Serum atherogenic indices, including cardiac risk ratio (CRR) and atherogenic coefficient, and plasma atherogenic index (AI) were calculated according to Dev et al. [38].

- $\quad \mathrm{CRR}=$ Total cholesterol/HDL cholesterol

- $\mathrm{AC}=($ Total cholesterol-HDL cholesterol $) / \mathrm{HDL}$ cholesterol.

Body weight at slaughter was calculated on day 35 as the average weight of $6 \mathrm{~h}$ fasted birds in each experimental group at the time of slaughter. Four birds (i.e., two males and two females per pen were used) were slaughtered by mechanical stunning and then bled near the occipital bone and atlas. Carcasses were individually wrapped in plastic bags and chilled for $24 \mathrm{~h}$ in a $5^{\circ} \mathrm{C}$ chilling room. The carcasses were subsequently weighed and cut into commercial parts. Carcass percentage, chilled carcass percentage, and cutting percentage were calculated following the method of Faria et al. [40]. $\mathrm{pH}$ values at $45 \mathrm{~min}$ and $24 \mathrm{~h}$ were determined by inserting electrodes into the breast meat samples and using a contact $\mathrm{pH}$ meter system (Model 205, Testo AG, Lenzkirch, Germany).

Breast meat (without skin) color was measured from the surface of the samples with a chromameter (Minolta 410, Japan), which was standardized with a white tile. Color was expressed in terms of CIE values for lightness $\left(\mathrm{L}^{*}\right)$, redness $\left(\mathrm{a}^{*}\right)$, and yellowness $\left(\mathrm{b}^{*}\right)$; these values were calculated from three readings at different positions according to Petracci et al. [41]. Hue angle and chroma were calculated according to Pathare et al. [42]. Water holding capacity (WHC), such as drip loss, cooking loss, trawling loss, and roasting loss, was determined according to Barbosa et al. [35].

Breast meat samples were collected to determine total cholesterol levels through the C45,994.10 
method according to AOAC [18]. Individual fatty acid contents were determined by isolating and analyzing each fatty acid through gas chromatography (HP6890; Agilent, Waldbronn, Germany). Fatty acids were quantified from their retention times in standard solutions by mass spectrometry (HP5973, Agilent) according to the method of Lepage and Roy [43]. Lipid quality index was calculated from fatty acid data, such as iodine value and ratio of saturated fatty acids to unsaturated fatty acids (SFA/USFA), according to Zhai et al. [44]. AI, $\Delta-9$ desaturase (16), and $\Delta-9$ desaturase (18) indices were evaluated according to He et al. [45]. Thrombogenicity index (TI) and ratio of hypocholesterolemic to hypercholesterolemic fatty acid ( $\mathrm{h} / \mathrm{H}$ ratio) were determined according to Loponte et al. [46].

\section{Statistical analysis}

The experimental data were evaluated by analysis of variance (ANOVA) with a completely randomized block design using the statistical model $Y_{i j}=\mu+T_{i}+e_{i j}$, where $\mu$ is the general mean, $T_{i}$ is the effect of treatment ( $\mathrm{i}=$ control and TABP supplementation at levels of 10,30 , and $50 \mathrm{~g} / \mathrm{kg}$ ), and $\mathrm{e}_{\mathrm{i}}$ is the random error associated with observation $Y_{i j .}$ ANOVA revealed significant differences, Tukey's honestly significant test was performed as described by Steel and Torrie [47] using $\mathrm{R}$ version 3.5.1 software as described by the $\mathrm{R}$ Core Team [48].

\section{Results}

This study assessed the productive performance of broiler chickens over 22-35 days and 0-35 days of rearing periods revealed that TABP supplementation at levels of 30 and $50 \mathrm{~g} / \mathrm{kg}$ led to higher feed intake, $\mathrm{BWG}$, and $\mathrm{ADG}$ compared with the control group $(p<0.05)$. Increases in level of TABP supplementation had a linear effect on total feed intake and daily feed intake $(p<0.01)$. BWG and ADG increased with increasing TABP supplementation levels in broiler diets in a linear manner $(\mathrm{p}<0.05)$, but TABP supplementation did not affect survival rates or the PI in all age groups of broiler chickens $(\mathrm{p}>0.05)$. When the economic return of feeding broilers with all levels of TABP supplementation was calculated, the FCG, SBR, NPR, and ROI of chicken production were not statistically different across all experimental groups $(p>0.05)$, as presented in Table- 2 .

The digestibility of nutrients and discovered that broilers provided a diet supplemented with TABP at levels of 10,30 , and $50 \mathrm{~g} / \mathrm{kg}$ have higher ether extract, crude fiber, and gross energy digestibility than the control group $(\mathrm{p}<0.05)$. TABP supplementation at $10 \mathrm{~g} / \mathrm{kg}$ also led to higher organic matter digestibility than the control and TABP $50 \mathrm{~g} / \mathrm{kg}$ group $(\mathrm{p}<0.01)$. Increases in TABP supplementation in broiler diets had a quadratic effect on ether extract, crude fiber, and gross energy digestibility $(\mathrm{p}<0.05)$, as shown in Table- 3 .

Broilers provided a diet with TABP supplementation at levels of 10,30 , and $50 \mathrm{~g} / \mathrm{kg}$ revealed greater numbers of cecal lactic acid bacteria (e.g.,
Lactobacillus and Bifidobacterium) and Enterococci than the control group $(\mathrm{p}<0.01)$. TABP supplementation at levels of 10,30 , and $50 \mathrm{~g} / \mathrm{kg}$ also showed the lower numbers of Samonella spp. in the cecum compared with the control group $(\mathrm{p}<0.01)$. The number of $E$. coli in the cecum of broilers given functional feed supplemented with TABP was lower than that of the control group, with significant differences in TABP groups at 30 and $\mathrm{mg} / \mathrm{kg}$. Increasing the level of TABP supplementation in broiler diets appeared to increase the number of lactic acid bacteria (e.g., Lactobacillus and Bifidobacterium) and Enterococcus spp. in the cecum (quadratic, $\mathrm{p}<0.01$ ). The numbers of Samonella spp. and E. coli in broiler chickens fed functional feed containing TABP supplementation decreased as the level of TABP supplementation increased in a quadratic $(p<0.01)$ and linear $(p<0.01)$ manner, respectively, as shown in Table-4. In addition, broilers fed diet supplemented with TABP at levels of 10,30 , and $50 \mathrm{~g} / \mathrm{kg}$ had higher levels of acetic, propionic, butyric, and total VFA in the cecum than the control group $(p<0.01)$. Total volatile fatty, acetic, propionic, and butyric acids in the cecum increased with the level of TABP supplementation in a quadratic manner $(\mathrm{p}<0.01)$, as shown in Table-4.

The small-intestinal histomorphology of broilers fed diet with TABP supplementation revealed that TABP supplementation at a level of $30 \mathrm{~g} / \mathrm{kg}$ of diets resulted in greater duodenal villus height (quadratic, $\mathrm{p}<0.01$ ), surface areas (linear, $p<0.01$ ), and height per cryptal depth ratio (quadratic, $p<0.01$ ) compared with the control group. Furthermore, broilers given functional feed with TABP supplementation at levels of 10,30 , and $50 \mathrm{~g} / \mathrm{kg}$ had higher jejunal villus heights, widths, and surface areas compared with the control group. These parameters increased with TABP in a quadratic manner $(\mathrm{p}<0.01)$, as shown in Table-5.

Table- 6 shows that the dressing percentage, cutting percentage, $\mathrm{pH}$, color $\left(\mathrm{L}^{*}, \mathrm{a}^{*}\right.$, and $\left.\mathrm{b}^{*}\right)$, and WHC of broilers provided a diet at all levels of TABP supplementation were not significantly different from those of the control group ( $>0.05)$. In addition, broilers provided diet with TABP supplementation at levels of 10,30 , and $50 \mathrm{~g} / \mathrm{kg}$ also had lower serum LDL cholesterol, triglycerides, and atherogenic indices of serum (cardiac risk ration and atherogenic coefficient) than broilers in the control group ( $\mathrm{p}<0.05)$. TABP supplementation at 30 and $50 \mathrm{~g} / \mathrm{kg}$ levels led to lower serum triglycerides compared with the controls $(p<0.05)$. LDL cholesterol, triglycerides, and atherogenic indices of serum in broiler chickens decreased linearly as the level of TABP supplementation increased $(p<0.05)$. TABP supplementation did not affect other hematological parameters, such as $\mathrm{RBC}$ concentration, $\mathrm{RBC}$ count, WBC count, $\mathrm{H}, \mathrm{L}$, and $\mathrm{H} / \mathrm{L}$ ratio $(\mathrm{p}>0.05)$, as shown in Table-7.

The results of the present experiment demonstrated that the level of TABP supplementation in broiler diets lowers cholesterol contents in chicken meat in a linear 
Table-2: Effects of TABP supplementation in broiler diets on productive performance and economic benefit return.

\begin{tabular}{|c|c|c|c|c|c|c|c|}
\hline \multirow[t]{2}{*}{ Parameters } & \multicolumn{4}{|c|}{$\begin{array}{l}\text { Level of TABP supplementation in } \\
\text { broiler diets }(\mathrm{g} / \mathrm{kg})\end{array}$} & \multirow[t]{2}{*}{ SEM } & \multirow[t]{2}{*}{ p-value } & \multirow[t]{2}{*}{$\begin{array}{l}\text { Trend } \\
\text { Analysis }\end{array}$} \\
\hline & $\mathbf{0}$ & 10 & 30 & 50 & & & \\
\hline \multicolumn{8}{|l|}{ Feed intake (kg/bird/day) } \\
\hline $0-21$ days & 1.29 & 1.22 & 1.31 & 1.39 & 0.18 & 0.06 & NS \\
\hline $22-35$ days & $2.52^{\mathrm{c}}$ & $2.62^{\mathrm{BC}}$ & $2.85^{A B}$ & $3.12^{\mathrm{A}}$ & 0.04 & $<0.01$ & $\mathrm{~L}$ \\
\hline $0-35$ days & $3.81^{\mathrm{c}}$ & $3.84^{\mathrm{BC}}$ & $4.16^{\mathrm{AB}}$ & $4.51^{\mathrm{A}}$ & 0.05 & $<0.01$ & $\mathrm{~L}$ \\
\hline \multicolumn{8}{|c|}{ Average daily feed intake (g/bird/day) } \\
\hline $0-21$ days & 61.68 & 58.29 & 64.42 & 66.31 & 0.85 & 0.06 & NS \\
\hline $22-35$ days & $179.72^{c}$ & $186.91^{\mathrm{BC}}$ & $203.48^{\mathrm{AB}}$ & $222.75^{\mathrm{A}}$ & 3.01 & $<0.01$ & $\mathrm{~L}$ \\
\hline $0-35$ days & $108.89^{c}$ & $109.74^{\mathrm{BC}}$ & $118.85^{\mathrm{B}}$ & $128.88^{A}$ & 1.36 & $<0.01$ & $\mathrm{~L}$ \\
\hline \multicolumn{8}{|c|}{ Body weight gain (kg/bird/day) } \\
\hline $0-21$ days & 0.87 & 0.81 & 0.83 & 0.84 & 0.01 & 0.40 & NS \\
\hline $22-35$ days & $1.09^{b}$ & $1.38^{\mathrm{a}}$ & $1.29^{a}$ & $1.39^{a}$ & 0.03 & 0.02 & $\mathrm{~L}$ \\
\hline $0-35$ days & $1.95^{\mathrm{b}}$ & $2.19^{a}$ & $2.12^{\mathrm{a}}$ & $2.23^{a}$ & 0.04 & 0.02 & $\mathrm{~L}$ \\
\hline \multicolumn{8}{|c|}{ Average daily gain (g/bird/day) } \\
\hline $0-21$ days & 41.30 & 38.64 & 39.60 & 39.99 & 0.52 & 0.40 & NS \\
\hline $22-35$ days & $77.61^{b}$ & $98.64^{a}$ & $92.11^{\mathrm{a}}$ & $99.40^{a}$ & 2.09 & 0.02 & $\mathrm{~L}$ \\
\hline $0-35$ days & $55.82^{b}$ & $62.64^{a}$ & $60.60^{a}$ & $63.75^{a}$ & 0.73 & 0.02 & $\mathrm{~L}$ \\
\hline \multicolumn{8}{|c|}{ Feed conversion ratio (Feed/Gain/day) } \\
\hline $0-21$ days & $1.49^{\mathrm{A}}$ & $1.51^{\mathrm{AB}}$ & $1.57^{\mathrm{C}}$ & $1.66^{\mathrm{D}}$ & 0.01 & $<0.01$ & $\mathrm{~L}$ \\
\hline $22-35$ days & 2.33 & 1.92 & 2.21 & 2.24 & 0.06 & 0.19 & NS \\
\hline $0-35$ days & 1.95 & 1.76 & 1.96 & 2.02 & 1.36 & 0.09 & NS \\
\hline \multicolumn{8}{|l|}{ Viability (\%) (day) } \\
\hline $0-21$ days & 98.33 & 100.00 & 100.00 & 100.00 & 0.42 & 0.44 & NS \\
\hline $22-35$ days & 91.23 & 8.25 & 96.49 & 100.00 & 1.52 & 0.27 & NS \\
\hline $0-35$ days & 89.47 & 98.25 & 96.49 & 100.00 & 1.24 & 0.07 & NS \\
\hline \multicolumn{8}{|l|}{ Productive index (day) } \\
\hline $0-21$ days & 271.47 & 255.44 & 251.74 & 240.97 & 14.37 & 0.13 & NS \\
\hline $22-35$ days & 204.43 & 346.82 & 270.23 & 296.31 & 17.08 & 0.09 & NS \\
\hline $0-35$ days & 256.60 & 353.76 & 299.04 & 315.71 & 11.14 & 0.08 & NS \\
\hline \multicolumn{8}{|l|}{ Economic benefit return (USD) } \\
\hline Feed cost per gain & 2.135 & 1.973 & 2.201 & 2.270 & 1.04 & 0.06 & NS \\
\hline Salable bird return & 2.258 & 2.312 & 2.312 & 2.312 & 0.43 & 0.44 & NS \\
\hline Net profits return per bird & 0.123 & 0.340 & 0.111 & 0.042 & 1.16 & 0.09 & NS \\
\hline Return of investment (\%) & 5.88 & 17.78 & 5.17 & 2.00 & 2.00 & 0.09 & NS \\
\hline
\end{tabular}

$a, b$ Mean with symbol with in same row differ significantly different $(p<0.05)$, A,BMean with symbol with in same row differ significantly different $(p<0.01), S E M=S t a n d a r d$ error of mean, NS=Not significantly different $(p>0.05)$, L=Linear. $\mathrm{TABP}=$ Trimmed asparagus by-products

Table-3: Effects of TABP supplementation in broiler diets on apparent nutrient digestibility.

\begin{tabular}{|c|c|c|c|c|c|c|c|}
\hline \multirow[t]{2}{*}{ Parameters (\%) } & \multicolumn{4}{|c|}{$\begin{array}{l}\text { Level of TABP supplementation in broiler } \\
\text { diets }(\mathrm{g} / \mathrm{kg})\end{array}$} & \multirow[t]{2}{*}{ SEM } & \multirow[t]{2}{*}{ p-value } & \multirow[t]{2}{*}{$\begin{array}{l}\text { Trend } \\
\text { analysis }\end{array}$} \\
\hline & $\mathbf{0}$ & 10 & 30 & 50 & & & \\
\hline Dry matter & 83.77 & 88.75 & 85.97 & 85.12 & 0.84 & 0.21 & NS \\
\hline Crude protein & 80.44 & 81.29 & 81.08 & 85.09 & 0.99 & 0.30 & NS \\
\hline Ether extract & $92.28^{c}$ & $96.62^{\mathrm{ab}}$ & $97.97^{a}$ & $95.55^{\mathrm{ab}}$ & 0.81 & 0.04 & Q2 \\
\hline Organic matter & $86.78^{\mathrm{B}}$ & $91.26^{A}$ & $87.82^{\mathrm{AB}}$ & $85.52^{B}$ & 0.41 & $<0.01$ & Q2 \\
\hline Gross energy & $87.44^{\mathrm{d}}$ & $91.29^{\mathrm{ab}}$ & $92.08^{\mathrm{a}}$ & $90.09^{\mathrm{bc}}$ & 0.60 & 0.02 & Q2 \\
\hline Crude fiber & $77.89^{c}$ & $82.60^{\mathrm{b}}$ & $87.05^{\mathrm{a}}$ & $80.79^{b}$ & 0.29 & 0.01 & Q2 \\
\hline
\end{tabular}

a,bMean with symbol with in same row differ significantly different $(p<0.05)$, A,BMean with symbol with in same row differ significantly different $(p<0.01), S E M=$ Standard error of mean, NS=Not significantly different $(p>0.05)$, and $\mathrm{Q} 2=\mathrm{Quadratic}$. TABP=Trimmed asparagus by-products

manner $(\mathrm{p}<0.01)$. TABP supplementation at levels of 30 and $50 \mathrm{~g} / \mathrm{kg}$ resulted in the lower SFA contents in meat than the control group $(\mathrm{p}<0.01)$. The results also revealed that broilers provided diet with TABP supplementation at levels of 10,30 , and $50 \mathrm{~g} / \mathrm{kg}$ had low levels of palmitic, oleic, and monounsaturated fatty acids (MUFAs) in their meat compared with the control. TABP supplementation decreased the iodine value and omega- 9 fatty acid content of chicken meat in a linear manner $(p<0.01)$ but had no effects on omega- 3 and omega- 6 contents in $(\mathrm{p}<0.05)$, as indicated in Table- 8 .

The effect of diet supplemented with TABP on the health indices of chicken meat was demonstrated in this study. Broilers given functional feed supplemented with TABP at levels of 10,30 , and $50 \mathrm{~g} / \mathrm{kg}$ had a lower AI than the control group (quadratic, $\mathrm{p}<0.05$ ). The $\Delta-9$ desaturase (16) and $\Delta-9$ desaturase (18) indices of meat from broiler chickens fed TABP at doses 
Table-4: Effects of TABP supplementation in broiler diets on cecal microbiota and volatile fatty acids content.

\begin{tabular}{|c|c|c|c|c|c|c|c|}
\hline \multirow[t]{2}{*}{ Parameters } & \multicolumn{4}{|c|}{$\begin{array}{l}\text { Level of TABP supplementation in broiler } \\
\text { diets }(\mathrm{g} / \mathrm{kg})\end{array}$} & \multirow[t]{2}{*}{ SEM } & \multirow[t]{2}{*}{ p-value } & \multirow[t]{2}{*}{$\begin{array}{l}\text { Trend } \\
\text { analysis }\end{array}$} \\
\hline & $\mathbf{0}$ & 10 & 30 & 50 & & & \\
\hline \multicolumn{8}{|c|}{ Cecal microbiology (Log10 colony-forming units/mL) } \\
\hline Lactic acid bacteria* & $11.35^{\mathrm{B}}$ & $11.94^{\mathrm{A}}$ & $12.36^{A}$ & $12.06^{\mathrm{A}}$ & 0.26 & $<0.01$ & Q2 \\
\hline Enterococci & $6.70^{\mathrm{B}}$ & $7.22^{\mathrm{A}}$ & $7.18^{\mathrm{A}}$ & $7.27^{\mathrm{A}}$ & 0.16 & $<0.01$ & Q2 \\
\hline E. coli & $8.17^{A}$ & $7.73 \mathrm{~A}^{\mathrm{B}}$ & $7.33^{\mathrm{B}}$ & $7.37^{\mathrm{B}}$ & 0.23 & $<0.01$ & L \\
\hline Salmonella & $3.73^{\mathrm{A}}$ & $3.29^{B}$ & $3.20^{\mathrm{B}}$ & $3.15^{\mathrm{B}}$ & 0.07 & $<0.01$ & Q2 \\
\hline \multicolumn{8}{|c|}{ Volatile fatty acids ( $\mu \mathrm{mol} / \mathrm{mL})$} \\
\hline Total volatile fatty acid & $67.69^{B}$ & $84.53^{A}$ & $80.15^{A}$ & $82.59^{A}$ & 1.36 & $<0.01$ & $\mathrm{C}$ \\
\hline Acetic acid & $48.30^{\mathrm{B}}$ & $57.20^{\mathrm{A}}$ & $54.48^{\mathrm{AB}}$ & $56.44^{A}$ & 1.18 & $<0.01$ & $\mathrm{C}$ \\
\hline Propionic acid & $9.05^{\mathrm{B}}$ & $11.05^{\mathrm{A}}$ & $10.40^{\mathrm{A}}$ & $10.48^{\mathrm{A}}$ & 0.17 & $<0.01$ & $\mathrm{C}$ \\
\hline Butyric acid & $9.50^{\mathrm{B}}$ & $11.50^{\mathrm{A}}$ & $10.74^{\mathrm{A}}$ & $11.00^{\mathrm{A}}$ & 0.18 & $<0.01$ & $\mathrm{C}$ \\
\hline
\end{tabular}

*Lactobacillus and Bifidobacteria, a,bMean with symbol with in same row differ significantly different $(p<0.05)$, $\mathrm{SEM}=$ Standard error of mean, NS=Not significantly different $(p>0.05)$, $L=$ Linear, $Q 2=$ Quadratic, $C=$ Cubic.

$\mathrm{TABP}=$ Trimmed asparagus by-products

Table-5: Effects of TABP supplementation in broiler diets on small intestinal histomorphology.

\begin{tabular}{|c|c|c|c|c|c|c|c|}
\hline \multirow[t]{2}{*}{ Parameters } & \multicolumn{4}{|c|}{$\begin{array}{l}\text { Level of TABP supplementation in broiler } \\
\text { diets }(\mathrm{g} / \mathrm{kg})\end{array}$} & \multirow[t]{2}{*}{ SEM } & \multirow[t]{2}{*}{ p-value } & \multirow[t]{2}{*}{$\begin{array}{l}\text { Trend } \\
\text { analysis }\end{array}$} \\
\hline & $\mathbf{0}$ & 10 & 30 & 50 & & & \\
\hline \multicolumn{8}{|l|}{ Duodenum } \\
\hline Villus height (mm) & $1.42^{\mathrm{C}}$ & $1.58^{\mathrm{AB}}$ & $1.65^{\mathrm{A}}$ & $1.51^{\mathrm{BC}}$ & 0.05 & $<0.01$ & Q2 \\
\hline Villus width (mm) & $0.14^{\mathrm{AB}}$ & $0.13^{\mathrm{B}}$ & $0.14^{A B}$ & $0.15^{\mathrm{A}}$ & 0.01 & $<0.01$ & Q2 \\
\hline $\operatorname{VSA}\left(\mathrm{mm}^{2}\right)$ & $0.61^{\mathrm{B}}$ & $0.65^{A B}$ & $0.70^{A}$ & $0.69^{A}$ & 0.03 & $<0.01$ & $\mathrm{~L}$ \\
\hline Cryptal depth (mm) & 0.22 & 0.24 & 0.22 & 0.23 & 0.01 & 0.104 & NS \\
\hline $\mathrm{VH}: \mathrm{CD}$ & $6.56^{\mathrm{B}}$ & $6.67^{\mathrm{AB}}$ & $7.48^{A}$ & $6.73^{A}$ & 0.03 & $<0.01$ & Q2 \\
\hline \multicolumn{8}{|l|}{ Jejunum } \\
\hline Villus height (mm) & $1.11^{\mathrm{B}}$ & $1.26^{\mathrm{A}}$ & $1.28^{\mathrm{A}}$ & $1.24^{\mathrm{A}}$ & 0.04 & $<0.01$ & Q2 \\
\hline Villus width (mm) & $0.14^{\mathrm{B}}$ & $0.16^{A}$ & $0.16^{A}$ & $0.15^{\mathrm{A}}$ & 0.01 & $<0.01$ & Q2 \\
\hline $\operatorname{VSA}\left(\mathrm{mm}^{2}\right)$ & $0.47^{\mathrm{B}}$ & $0.64^{A}$ & $0.64^{\mathrm{A}}$ & $0.61^{A}$ & 0.03 & $<0.01$ & Q2 \\
\hline Cryptal depth (mm) & $0.21^{\mathrm{B}}$ & $0.23^{A B}$ & $0.24^{\mathrm{A}}$ & $0.22^{\mathrm{AB}}$ & 0.01 & $<0.01$ & Q2 \\
\hline $\mathrm{VH}: \mathrm{CD}$ & 5.30 & 5.62 & 5.41 & 5.56 & 0.26 & 0.36 & NS \\
\hline \multicolumn{8}{|l|}{ Ileum } \\
\hline Villus height (mm) & 0.76 & 0.85 & 0.87 & 0.81 & 0.05 & 0.10 & NS \\
\hline Villus width (mm) & 0.14 & 0.13 & 0.13 & 0.12 & 0.01 & 0.43 & NS \\
\hline $\operatorname{VSA}\left(\mathrm{mm}^{2}\right)$ & $0.24^{\mathrm{B}}$ & $0.33^{A}$ & $0.34^{\mathrm{A}}$ & $0.33^{A}$ & 0.01 & $<0.01$ & Q2 \\
\hline Cryptal depth (mm) & $0.15^{\mathrm{c}}$ & $0.16^{\mathrm{B}}$ & $0.17^{A}$ & $0.17^{A B}$ & 0.01 & $<0.01$ & Q2 \\
\hline $\mathrm{VH}: \mathrm{CD}$ & 5.293 & 5.296 & 5.029 & 5.243 & 0.27 & 0.51 & NS \\
\hline
\end{tabular}

$A, B$ Mean with symbol within same row differ significantly different $(p<0.01)$, SEM=Standard error of mean, NS=Not significantly different $(p>0.05)$, $L=$ Linear, and $Q 2=$ Quadratic, VSA=Villus surface area, VH:CD=Villus height: Crypt depth. TABP=Trimmed asparagus by-products

of 10,30 , and $50 \mathrm{~g} / \mathrm{kg}$ were higher than those of control broilers $(\mathrm{p}<0.05)$. However, broilers provided diet supplemented with TABP at levels of 10 and $30 \mathrm{~g} / \mathrm{kg}$ revealed a $\Delta-9$ desaturase (18) index of meat similar to that of the control group ( $>00.05)$. TABP supplementation increased the $\Delta-9$ desaturase (16) index; for TI a decrease is shown in Table- 7 and $\mathrm{h} / \mathrm{H}$ ratio of chicken meat in a quadratic manner $(\mathrm{p}<0.05)$, as indicated in Table-8.

\section{Discussion}

The results of this study revealed that feeding TABP prebiotics to broilers could increase their ether extract, organic matter, gross energy, and crude fiber digestibility. Huang et al. [7] reported that asparagus contains high levels of FOS and inulin. These substances are classified as prebiotics because they help beneficial bacteria survive and grow in the gut [49].
Beneficial bacteria, also known as gut local probiotics, aid in the digestion and utilization of nutrients in monogastric animals [50]. Carbohydrate digestibility increased in the cecum because, as the main fermentation site in chickens, it contains a large number of microorganisms [51]. The digestive enzymes of monogastric animals are unable to digest FOS. Probiotics in the hindgut, such as lactic acid bacteria (e.g., Bifidobacterium spp. and Lactobacillus spp.) and Enterococcus spp., can digest FOS completely and produce gas, lactic acid, and SCFAs through carbohydrate fermentation [52]. The findings of the present experiments are consistent with those of Yun et al. [53], who found that prebiotic-treated broilers have higher dry matter digestibility than controls, as well as those of Huang et al. [7], who suggested that prebiotic and probiotic supplementation can improve nutrient digestion and absorption, leading to improved 
Table-6: Effects of TABP supplementation in broiler diets on carcass and meat quality.

\begin{tabular}{|c|c|c|c|c|c|c|c|}
\hline \multirow[t]{2}{*}{ Parameters } & \multicolumn{4}{|c|}{$\begin{array}{l}\text { Level of TABP supplementation in broiler } \\
\text { diets }(\mathbf{g} / \mathbf{k g})\end{array}$} & \multirow[t]{2}{*}{ SEM } & \multirow[t]{2}{*}{ p-value } & \multirow[t]{2}{*}{$\begin{array}{l}\text { Trend } \\
\text { Analysis }\end{array}$} \\
\hline & $\mathbf{0}$ & 10 & 30 & 50 & & & \\
\hline \multicolumn{8}{|c|}{ Carcass and cutting percentage (\%) } \\
\hline Thai carcass & 84.02 & 85.65 & 83.89 & 83.53 & 0.71 & 0.73 & NS \\
\hline Dressing percentage & 75.95 & 77.45 & 76.96 & 76.34 & 0.43 & 0.64 & NS \\
\hline Chilled percentage & 74.43 & 75.90 & 75.42 & 74.82 & 0.42 & 0.63 & NS \\
\hline Breast & 25.20 & 29.65 & 28.57 & 29.58 & 0.28 & 0.42 & NS \\
\hline Fillets & 4.56 & 5.12 & 4.78 & 5.21 & 0.12 & 0.34 & NS \\
\hline Wing & 10.88 & 10.90 & 10.90 & 11.47 & 0.17 & 0.57 & NS \\
\hline Thigh & 16.81 & 18.08 & 18.06 & 16.79 & 0.32 & 0.34 & NS \\
\hline Drum strict & 11.01 & 11.58 & 11.20 & 11.29 & 0.17 & 0.69 & NS \\
\hline Head & 6.41 & 6.81 & 6.09 & 6.03 & 0.25 & 0.69 & NS \\
\hline Shank & 3.35 & 3.32 & 3.56 & 3.42 & 0.11 & 0.86 & NS \\
\hline Skeletal & 18.91 & 17.21 & 20.73 & 18.39 & 0.21 & 0.02 & NS \\
\hline Internal organ & 11.82 & 10.22 & 11.89 & 12.32 & 0.23 & 0.12 & NS \\
\hline \multicolumn{8}{|l|}{ Meat quality } \\
\hline $\mathrm{pH} \mathrm{O}$ & 6.21 & 6.18 & 6.32 & 6.29 & 0.37 & 0.59 & NS \\
\hline $\mathrm{pH} 24$ & 5.92 & 5.89 & 5.90 & 5.99 & 0.14 & 0.48 & NS \\
\hline \multicolumn{8}{|c|}{ Color at $24 \mathrm{~h}$ after chilled storage at $4^{\circ} \mathrm{C}$} \\
\hline Lightness ( $\left.L^{*}\right)$ & 55.87 & 52.50 & 56.80 & 55.63 & 0.66 & 0.19 & NS \\
\hline Redness (a*) & 0.36 & 0.54 & 0.55 & 0.47 & 0.17 & 0.45 & NS \\
\hline Yellowness $\left(b^{*}\right)$ & 9.76 & 9.54 & 10.07 & 10.31 & 0.43 & 0.92 & NS \\
\hline Chroma & 0.001 & 0.003 & 0.003 & 0.002 & 0.00 & 0.03 & NS \\
\hline Hue angle & 1.53 & 1.51 & 1.52 & 1.53 & 0.10 & 0.17 & NS \\
\hline \multicolumn{8}{|c|}{ Water holding capacity (\%) } \\
\hline Drip loss & 4.55 & 4.11 & 4.38 & 4.57 & 0.25 & 0.91 & NS \\
\hline Cooking loss & 21.75 & 23.04 & 21.39 & 22.43 & 0.86 & 0.90 & NS \\
\hline Trawling loss & 10.01 & 9.00 & 11.66 & 6.69 & 0.88 & 0.31 & NS \\
\hline Roasting loss & 21.06 & 20.29 & 18.23 & 19.94 & 0.77 & 0.63 & NS \\
\hline
\end{tabular}

$\mathrm{SEM}=$ Standard error of mean, NS=Not significantly different $(\mathrm{p}>0.05) . \mathrm{TABP}=$ Trimmed asparagus by-products

Table-7: Effects of TABP supplementation in broiler diets on blood parameter and serum biochemistry.

\begin{tabular}{|c|c|c|c|c|c|c|c|}
\hline \multirow[t]{2}{*}{ Parameters } & \multicolumn{4}{|c|}{$\begin{array}{c}\text { Level of TABP supplementation in } \\
\text { broiler diets }(\mathrm{g} / \mathrm{kg})\end{array}$} & \multirow[t]{2}{*}{ SEM } & \multirow[t]{2}{*}{ p-value } & \multirow[t]{2}{*}{$\begin{array}{l}\text { Trend } \\
\text { analysis }\end{array}$} \\
\hline & $\mathbf{0}$ & 10 & 30 & 50 & & & \\
\hline \multicolumn{8}{|l|}{ Blood parameter } \\
\hline White blood cell $\left(10^{9} / \mathrm{mm}^{3}\right)$ & 15.93 & 11.76 & 18.40 & 30.66 & 3.07 & 0.23 & NS \\
\hline Lymphocyte (\%) & 54.67 & 60.67 & 49.33 & 50.33 & 4.14 & 0.76 & NS \\
\hline Heterophile (\%) & 35.33 & 34.67 & 42.33 & 44.00 & 3.86 & 0.77 & NS \\
\hline $\mathrm{H} / \mathrm{L}$ ratio & 0.66 & 0.61 & 1.01 & 1.09 & 0.17 & 0.69 & NS \\
\hline Red blood cell $\left(\times 10^{6} / \mathrm{mm}^{3}\right)$ & 1.67 & 2.00 & 1.67 & 2.40 & 0.12 & 0.20 & NS \\
\hline Hemoglobin $(\mathrm{g} / \mathrm{dL})$ & 13.00 & 13.33 & 13.67 & 13.73 & 0.21 & 0.58 & NS \\
\hline Hematocrit $(\%)$ & 22.67 & 26.33 & 22.00 & 34.33 & 2.02 & 0.19 & NS \\
\hline \multicolumn{8}{|l|}{ Serum biochemistry (mg/dL) } \\
\hline Cholesterol & 178.67 & 182.33 & 197.00 & 173.67 & 2.12 & 0.57 & NS \\
\hline High-density lipoprotein cholesterol & 119.00 & 124.33 & 121.00 & 125.00 & 3.03 & 0.88 & NS \\
\hline Low-density lipoprotein cholesterol & $53.00^{\mathrm{A}}$ & $45.33^{\mathrm{B}}$ & $46.33^{B}$ & $37.33^{c}$ & 0.33 & 0.04 & $\mathrm{~L}$ \\
\hline Triglyceride & $60.33^{A}$ & $63.67^{\mathrm{A}}$ & $57.33^{B}$ & $57.00^{\mathrm{B}}$ & 0.48 & 0.02 & $\mathrm{~L}$ \\
\hline \multicolumn{8}{|l|}{ Atherogenic indices of serum } \\
\hline Cardiac risk ratio & $1.56^{\mathrm{A}}$ & $1.46^{\mathrm{B}}$ & $1.48^{\mathrm{B}}$ & $1.40^{\mathrm{B}}$ & 0.02 & 0.02 & L \\
\hline Atherogenic coefficient & $0.56^{A}$ & $0.46^{\mathrm{B}}$ & $0.48^{\mathrm{B}}$ & $0.40^{\mathrm{B}}$ & 0.02 & 0.02 & $\mathrm{~L}$ \\
\hline
\end{tabular}

$A, B$ Mean with symbol within same row differ significantly different $(p<0.01)$, SEM=Standard error of mean, NS=Not significantly different $(p>0.05), L=$ Linear

chicken performance. Meng et al. [54] discovered that supplementing prebiotics derived from oligosaccharides can improve the dry matter and protein digestibility of broilers.

This study found that supplementation of broiler feed with TABP increases VFA production and the number of beneficial microorganisms, such as lactic acid bacteria (e.g., Lactobacillus and Bifidobacterium) and Enterococcus, in the guts of broiler chickens relative to those in the control group. TABP supplementation could also reduce the numbers of Samonella spp. and E. coli compared with the control. According to Józefiak et al. [51], the prebiotics beta-glucan and inulin could increase the yield of short-chain VFAs (e.g., acetic acid, propionic acid, and butyric acid) in the gut through microbial oligosaccharide fermentation. 
Table-8: Effects of TABP supplementation in broiler diets on fatty acid profile in meat.

\begin{tabular}{|c|c|c|c|c|c|c|c|}
\hline \multirow[t]{2}{*}{ Parameters } & \multicolumn{4}{|c|}{$\begin{array}{l}\text { Level of TABP supplementation in broiler } \\
\text { diets }(\mathrm{g} / \mathrm{kg})\end{array}$} & \multirow[t]{2}{*}{ SEM } & \multirow[t]{2}{*}{ p-value } & \multirow[t]{2}{*}{$\begin{array}{l}\text { Trend } \\
\text { analysis }\end{array}$} \\
\hline & $\mathbf{0}$ & 10 & 30 & 50 & & & \\
\hline Cholesterol $(\mathrm{g} / 100 \mathrm{~g})$ & $72.50^{\mathrm{A}}$ & $72.37^{A}$ & $71.01^{\mathrm{AB}}$ & $68.25^{\mathrm{B}}$ & 1.49 & 0.01 & L \\
\hline \multicolumn{8}{|c|}{ Fatty acid profile in meat $(\mathrm{g} / 100 \mathrm{~g})$} \\
\hline Myristic acid & 0.01 & 0.01 & 0.01 & 0.01 & 0.00 & 0.00 & NS \\
\hline Palmitic acid & $0.48^{\mathrm{A}}$ & $0.38^{\mathrm{B}}$ & $0.36^{\mathrm{B}}$ & $0.32^{\mathrm{B}}$ & 0.04 & $<0.01$ & $\mathrm{~L}$ \\
\hline Palmitoleic acid & 0.08 & 0.07 & 0.06 & 0.06 & 0.06 & 0.42 & NS \\
\hline Stearic acid & 0.10 & 0.10 & 0.13 & 0.14 & 0.01 & 0.07 & NS \\
\hline Vaccenic acid & 0.03 & 0.03 & 0.03 & 0.03 & 0.04 & 0.69 & NS \\
\hline Oleic acid & $0.62^{\mathrm{A}}$ & $0.52^{\mathrm{B}}$ & $0.48^{B}$ & $0.41^{c}$ & 0.03 & $<0.01$ & $\mathrm{~L}$ \\
\hline Linoleic acid & 0.24 & 0.02 & 0.22 & 0.22 & 0.02 & 0.71 & NS \\
\hline Linolenic acid & 0.01 & 0.01 & 0.01 & 0.01 & 0.00 & 0.00 & NS \\
\hline Eicosenoic acid & 0.01 & 0.01 & 0.01 & 0.01 & 0.00 & 0.00 & NS \\
\hline Arachidonic acid & 0.01 & 0.01 & 0.02 & 0.01 & 0.03 & 0.67 & NS \\
\hline$\Sigma S F A$ & $0.63^{A}$ & $0.53^{\mathrm{AB}}$ & $0.51^{B}$ & $0.47^{B}$ & 0.05 & $<0.01$ & $\mathrm{~L}$ \\
\hline$\Sigma M U F A$ & $0.75^{\mathrm{A}}$ & $0.64^{\mathrm{B}}$ & $0.59^{B}$ & $0.52^{c}$ & 0.03 & $<0.01$ & $\mathrm{~L}$ \\
\hline$\sum$ PUFA & 0.26 & 0.26 & 0.25 & 0.24 & 0.02 & 0.84 & NS \\
\hline EOmega 3 & 0.01 & 0.01 & 0.01 & 0.01 & 0.00 & 0.00 & NS \\
\hline EOmega 6 & 0.25 & 0.25 & 0.24 & 0.23 & 0.02 & 0.84 & NS \\
\hline ¿Omega 9 & $0.63^{A}$ & $0.53^{\mathrm{B}}$ & $0.49^{\mathrm{B}}$ & $0.42^{c}$ & 0.03 & $<0.01$ & $\mathrm{~L}$ \\
\hline \multicolumn{8}{|l|}{ Quality of fat in meat } \\
\hline SFA/USFA ratio & 0.63 & 0.59 & 0.60 & 0.62 & 0.06 & 0.76 & NS \\
\hline Iodine value & $1.08^{\mathrm{A}}$ & $0.98^{\mathrm{B}}$ & $0.93^{\mathrm{BC}}$ & $0.86^{c}$ & 0.04 & $<0.01$ & $\mathrm{~L}$ \\
\hline $\mathrm{n} 3 / \mathrm{n} 6$ ratio & 0.04 & 0.04 & 0.04 & 0.04 & 0.00 & 0.75 & NS \\
\hline Atherogenic index & $0.55^{a}$ & $0.47^{b}$ & $0.48^{\mathrm{b}}$ & $0.47^{b}$ & 0.04 & 0.04 & Q2 \\
\hline$\Delta-9$ desaturase (16) index & $12.87^{\mathrm{B}}$ & $15.94^{\mathrm{A}}$ & $14.72^{\mathrm{AB}}$ & $15.81^{\mathrm{A}}$ & 0.14 & 0.04 & Q2 \\
\hline$\Delta-9$ desaturase (18) index & $81.20^{\mathrm{A}}$ & $79.26^{A}$ & $78.06^{\mathrm{AB}}$ & $74.27^{\mathrm{B}}$ & 1.97 & $<0.01$ & $\mathrm{~L}$ \\
\hline Thrombogenicity index & $1.12^{\mathrm{a}}$ & $1.03^{\mathrm{b}}$ & $1.04^{\mathrm{b}}$ & $1.05^{\mathrm{b}}$ & 0.02 & 0.04 & Q2 \\
\hline $\mathrm{h} / \mathrm{H}$ ratio & $1.83^{\mathrm{b}}$ & $1.97^{a}$ & $1.97^{\mathrm{a}}$ & $1.99^{a}$ & 0.03 & 0.03 & Q2 \\
\hline
\end{tabular}

a,bMean with symbol within same row differ significantly different $(p<0.05)$, A,BMean with symbol within same row differ significantly different $(p<0.01)$, SEM =Standard error of mean, NS=Not significantly different $(p>0.05), L=L i n e a r$, and $\mathrm{Q} 2=$ Quadratic. TABP $=$ Trimmed asparagus by-products

Short-chain VFAs are important for the physiological processes of the intestinal microflora and can help improving gut health by modulating the microbial ecology [55]. Shang et al. [10] reported the prevalence of unique bacteria in broilers fed FOS supplements, such as Akkermansia (a mucin-degrading bacterium), Janthinobacterium and Butyrivibrio (butyrate-producing bacteria), Coprococcus (a butyrate-producing bacterium), and Paludibacter (a propionate-producing bacterium). FOS supplementation can increase the numbers of these bacteria at the epithelial wall of the ileum, improve intestinal immunity, and increase the membrane absorption area of nutrients [10,56,57]. These phenomena may inhibit some pathogenic bacteria and reduce the colonization of organisms such as Salmonella and Campylobacter. The crop, gizzard, and duodenum contain similar microorganisms up to $99 \%$ lactobacilli [58], resulting in an acidic ecology that is unsuitable for harmful bacterial growth, development, and division. Increases in fermentation activity and VFA content could be correlated with increased acidity, which results in pathogenic inhibition effects and increased nutrient digestibility [59]. Buclaw [60] described the ability of Bifidobacterium and Lactobacillus spp. to produce natural antibiotic substances with a broad spectrum of action, such as lactocin, helveticin, covaxin, nisin, and indocin. Furthermore, bacteria can produce bacteriocin, which inhibits the growth of E. coli; Bifidobacterium, and Lactobacillus can produce organic acids, that is, lactic acid and acetic acid, to suppress pathogenic pathogens in the gastrointestinal tract, that is, Salmonella, Campylobacter, and E. coli [61].

According to Ahmed et al. [62], increases in VFA may be attributed to the presence of inulin and oligosaccharides affect the reduction of pathogenic microorganisms in the cecum [10]. FOS can help maintain a healthy digestive environment by increasing the number of Bifidobacterium or decreasing the number of $E$. coli in the digestive tract. The findings of the present study are consistent with the results of many previous studies demonstrating the potential applications of prebiotics. Csernus and Czeglédi [63] found that high levels of FOS supplementation could boost microorganisms' production of VFA, leading to improvement of host's gut ecology. Biochemical studies and microbiological cultures showed that dietary FOS supplementation could increase gut fermentation, increase VFA production, stimulate the growth of beneficial bacteria, such as bifidobacteria and lactobacilli, and inhibit the growth of pathogenic microorganisms, such as Salmonella spp., Clostridium perfringens, and E. coli in broilers [64]. Supplementation with $0.25 \%$ FOS and $0.05 \%$ MOS or the antibiotic avilamycin could reduce the numbers of $C$. perfringens and E. coli; treatment with $0.25 \%$ FOS and $0.25 \%$ MOS 
also demonstrated a direct effect on the increase and diversity of lactobacilli in the ileum [65]. Geier et al. [66] reported that broilers fed $5 \mathrm{~g} / \mathrm{kg}$ FOS show increased numbers of microorganisms in the ileum than the control group. The increased abundance of Lactobacillus and Bifidobacterium in the intestinal microflora of broilers fed prebiotics observed in the present study is similar to the results of Gaggìa et al. [67]. Some potential mechanisms that could explain the health benefits of prebiotics in altering the gut microbiota include competitive exclusion of pathogens [68], production of antimicrobial factors [69], stimulation of the immune system [70], and development of intestinal morphology [71].

The findings of this work indicated that broilers fed prebiotics from TABP have higher duodenal villus heights, widths, and surface areas compared with control birds because the epithelial cells of the small intestine use SCFAs produced by microbial fermentation as an energy source to stimulate the development and to increase the integrity of the intestinal mucosa. Increases in the number of beneficial microorganisms could reduce the number of harmful microorganisms directly affecting the villi; some harmful microorganisms, for example, produce toxins, such as botulinum toxin from Clostridium botulinum that destroy villus cells. Ahmed et al. [62] described the primary mechanism of prebiotics in promoting the growth of lactic acid-producing bacteria and their effect on increasing the concentration of SCFAs (e.g., acetic, propionic, and butyric acids), which are an important source of energy for colon cells and stimulate the intestines [72]. SCFAs provide energy to cell membranes and indirectly lower the cecum $\mathrm{pH}$ to prevent pathogen growth and increase mineral uptake [71]. Butyric acid is an important source of energy for epithelial cells and helps to suppress the inflammatory response by inhibiting pro-inflammatory cytokines [73]. According to Eeckhaut et al. [73], butyric acid provides energy to epithelial cells and resists the inflammatory response induced by pro-inflammatory cytokines.

Acetic acid is used as a solidifier in the formation of fats and cholesterol, while propionic acid is used as a solidifier in gluconeogenesis; the latter also inhibits fatty acid and lipid synthesis. Over 200 non-starch polysaccharide-degrading enzymes and pathways involved in the production of SCFAs have been discovered in the metagenomic analysis of the cecal microbiota [74]. The present research was consistent with the previous research demonstrating the potential of prebiotics in broiler diets to develop intestinal mucosal structures and villus heights [75] and improves gastrointestinal health and strength [49]. Considering the potential ability of prebiotics from dietary TABP supplementation to increase digestibility, improve intestinal ecology, and enhance the intestinal morphology, such supplementation may help improve feed utilization efficiency and growth performance of broilers.
The findings of the present study clearly demonstrated the effect of TABP supplementation into broiler diets on feed intake, weight gain, and no significant differences for PI in Table-1. These findings are consistent with the results of Kim et al. [65], who found that $0.5 \%$ FOS prebiotic supplementation increases ADGs compared with the control group; however, the authors also found that FCR and survival rates are similar across all experimental groups. Józefiak et al. [51] reported that beta-glucan and inulin could increase BWG and FCR. The current study also confirmed that TABP prebiotic supplementation does not affect carcass characteristics and meat quality, which is consistent with the findings of Abdel-Hafeez et al., [76] who reported that prebiotic supplementation in broiler diets does not affect carcass, breast meat, and visceral percentages, including the liver, heart, and small intestine. Guaragnia et al. [77] indicated that inulin supplementation with probiotics does not affect the $\mathrm{L}^{*}, \mathrm{a}^{*}$, and $\mathrm{b}^{*}$ color values, shear force values, and WHC of meat.

Dietary USFAs help lowering cholesterol, which is associated with coronary heart disease. PUFAs are associated with lower plasma LDL levels and the total cholesterol ratio [78]. The present study highlights the effect of TABP prebiotic supplementation on serum LDL cholesterol and triglyceride levels, as well as total cholesterol contents in chicken breast meat. The findings are consistent with those of the previous studies describing the lowering of serum cholesterol by supplementation with dietary oligosaccharides and [79] or Spirulina platensis [80,81]. Aktimur et al. [82] reported that the use of probiotics, prebiotics, and symbiotic lower total cholesterol, LDL cholesterol, and triglycerides in rats with high blood cholesterol levels. Lactobacillus plantarum LS/07 reduced total and LDL cholesterol, while L. plantarum Biocenol LP96 reduced triglycerides and very low-density lipoprotein without affecting serum HDL cholesterol and hepatic lipids [83]. A substantial body of evidence supports the assumptions about the mechanisms of prebiotic and probiotic supplementation in diets in cholesterol reductions.

The previous research described a mechanism of bacterial cholesterol absorption involving the binding of cholesterol to the bacterial cell wall [3] and then to the phospholipid bilayer membrane of probiotic cells [84]. Shehata et al. [85] discovered that growing bacterial cells deposit large amounts of cholesterol and that sonication stimulates cholesterol production in Bifidobacterium breve ATCC 15700 cells by over $40 \%$. However, the binding of cholesterol to growing probiotic cells is highly stable. In vitro experiment revealed that the amount of cholesterol removal decreased when probiotics were grown. This finding suggests that cholesterol is removed not only by live probiotics during maturation but also by dead cells [86]. A compelling explanation for the reduction of cholesterol associated with bile formation has also 
been presented. According to Wang et al. [87], lactic acid bacteria may lower blood cholesterol by stimulating bile acid excretion in the stool, which increases the deconjugation and fecal excretion of bile acids [88]. This mechanism is believed to be an indirect means for prebiotics to lower cholesterol. The reduction in cholesterol is most likely due to the combination of pro- and prebiotics involved in the production of $\mathrm{BSH}$, which catalyzes the breakdown of conjugated bile salts into unconjugated bile salts, such as glycol- and tauro-bile acids. The latter are absorbed less extensively than conjugated bile salts, resulting in greater bile excretion through the feces [86].

Dietary fiber inhibits bile reabsorption into the liver by increasing bile excretion, which results in a decrease in bile in the liver and stimulation of bile synthesis via the enzyme 7-hydroxylase. In addition, soluble fatty acids can inhibit cholesterol synthesis and stimulate bile production, affecting cholesterol reduction in the blood [89]. Acetic acid is converted to acetyl-coA, which acts as a precursor for cholesterol biosynthesis in the liver, and butyric acid is involved in the oxidation of mitochondrial fatty acids into acetyl-coA products [90]. Butyric acid inhibits the synthesis of cholesterol in the liver and serves as an energy source for human colon epithelial cells. Propionic acid inhibits fatty acid synthesis in the liver, reduces the rate of triacylglycerol secretion, and lowers overall cholesterol synthesis levels, leading to lower blood cholesterol levels [33]. According to Mistry et al. [91], increased acetic and butyric acid contents could be observed in the manure of inulin-treated animals and in vitro addition of propionic acid to hepatocytes reductase activity. This finding is consistent with the results of Kim et al. [92], who reported that SCFAs inhibit 3-hydroxy-3-methyl-glutaryl-coenzyme A (HMG CoA) reductase activity. Ooi [16] described the mechanism of conversion of cholesterol to coprostenol by probiotic cholesterol reductase and the inhibition of HMG CoA reductase by probiotics. HMG CoA is associated with a cholesterol synthesis pathway [89]. When cholesterol is reduced in the liver, HMG CoA reductase stimulates the synthesis of cholesterol and LDL receptors in the liver and the transport of cholesterol from the bloodstream to liver cells, resulting in decreases in blood cholesterol levels and cholesterol accumulation.

The present experiments showed that TABP supplementation could reduce the contents of palmitic acid, oleic acid, SFAs, and MUFAs in broiler chickens but had no effect on the latter's omega- 3 and omega- 6 fatty acids. These findings are consistent with those of previous studies. Kalavathy et al. [93] found that probiotic supplementation is effective in lowering monounsaturated, oleic, and SFAs. Bonos et al. [94] demonstrated that the fatty acid composition of meat can be altered by microorganisms in the gastrointestinal tract because these microorganisms can hydrogenate USFAs to SFAs. Probiotics could also reduce the oleic acid contents of rat liver [95] and chicken breast [96]. Kalavathy et al. [93] revealed that Lactobacillus supplementation of broiler feed does not affect the polyUSFA contents of the chicken meat when compared with controls. Hossain et al. [97] found that herbs and probiotics increase arachidonic acid, DHA, and PUFA levels and decrease omega- 6 fatty acids in breast meat. Kim et al. [65] found that prebiotic supplementation can increase linoleic acid contents but decrease arachidonic acid contents in chicken breast meat; no effect on PUFA levels was observed. Stearic and SFA proportions decreased whereas linoleic and PUFA contents increased in breast and thigh meat of broilers fed probiotics and cassava extracts [98]. A definitive mechanism to explain the effect of dietary probiotics on the regulation of palmitic acid contents in chicken breast meat has been proposed. Rodrigues et al. [99] reported that oligosaccharides with structures similar to those of FOS and inulin affect fatty acid levels to different extents because of differences in expression level and/or oligosaccharide-degrading enzyme activity Gomaa [100] discovered a link between consumer's blood cholesterol and dietary levels of C16:0 and C14:0; specifically, C14:0 fatty acids induced greater increases in blood cholesterol compared with C16:0 fatty acids, and the latter had no effect on LDL and HDL changes. The findings of this study implied that changes in fatty acid ratio in egg yolks could result in lower cardiovascular disease risk factors (e.g., TI) and Ross et al. [101] discovered that probiotics could decrease the AI of functional foods. The present experiment results demonstrated that prebiotic supplementation could increase the metabolic disease inhibitory index (i.e., $\Delta-9$ desaturase index) value and $\mathrm{h} / \mathrm{H}$ ratio of chicken meat. Salah et al. [102] similarly found that probiotics increase the $\mathrm{h} / \mathrm{H}$ ratio in animals; according to the findings of this study, the chicken meat obtained from broilers supplemented with APT as a dietary prebiotic, is suitable for use in functional food.

\section{Conclusion}

Supplementation of broiler functional feed with TABP may increase the apparent digestibility of ether extract, crude fiber, and gross energy. TABP supplementation increased the yield of short-chain VFA in the hind gut, which promoted the proliferation of lactic acid bacteria and Enterococcus spp., and decreased the numbers of Salmonella spp. and E. coli. Broilers fed with TABP diet showed increased villus height and crypt of Lieberkühn depth of the duodenum, jejunum, and ileum, which could contribute to increased FI and ADG without changes in the carcass and meat quality. Supplementation of broiler diet with TABP reduced total cholesterol and triglyceride in serum, atherogenic indices of serum, as well as total cholesterol, palmitic acid, oleic acid, SFA, and MUFAs in breast meat. The addition of TABP to the broiler diet could also reduce AI and TI and increase the $\Delta-9$ desaturase (16) index and $\mathrm{h} / \mathrm{H}$ ratio of broiler meat, 
suggesting the resultant meat products as a healthy food. The results demonstrated that supplementation of $30 \mathrm{~g} / \mathrm{kg}$ TABP optimally improves broiler performance and meat production. This research contributes to the guideline of using TABP to resolve the problem of agricultural waste, improve by-product value addition and broiler meat product development as functional foods to promote consumer health.

\section{Authors' Contributions}

$\mathrm{MN}$ : Conceptualized, data collection and analysis, and drafted the manuscript. $\mathrm{MNa}$ and $\mathrm{VC}$ : Husbandry and data collection. PS: Laboratory and data collection. SC: Review manuscript and editing. WK: Data analysis. All authors read and approved the final manuscript.

\section{Acknowledgments}

We would like to thank the NRC of Thailand and the Silpakorn University Research, Innovation, and Creativity Administration Office for financially supporting this project (Grant no. SURDI 58/01/45). We are also grateful to the Agricultural Technology Training and Transfer Center, Faculty of Animal Science and Agricultural Technology, Silpakorn University, Phetchaburi IT campus for providing husbandry units and laboratory. We thank farmersfrom The Royal Project of Hub Kapong, Cha Am, Phetchaburi, for supplying asparagus samples used in this study.

\section{Competing Interests} interests.

The authors declare that they have no competing

\section{Publisher's Note}

Veterinary World remains neutral with regard to jurisdictional claims in published institutional affiliation.

\section{References}

1. Bharathi, S., Cheryl, A., Rajagopalasamy, C.B.T., Uma, A., Ahilan, B. and Aanand, S. (2019) Functional feed additives used in fish feeds. Int. J. Fish. Aquat. Stud., 7(3): 44-52.

2. Wang, X., Farnell, Y.Z., Peebles, E.D., Kiess, A.S., Wamsley, K.G.S. and Zhai, W. (2016) Effects of prebiotics, probiotics, and their combination on growth performance, small intestine morphology, and resident Lactobacillus of male broilers. Poult. Sci., 95(6): 1332-1340.

3. Kumar, M., Nagpal, R., Kumar, R., Hemalatha, R., Verma, V., Kumar, A., Chakraborty, C., Singh, B., Marotta, F., Jain, S. and Yadav. H. (2012) Cholesterol-lowering probiotics as potential biotherapeutics for metabolic diseases. Exp. Diabetes Res., 2012(3): 902917.

4. Nopparatmaitree, M., Panthong, A., Paengkoum, S. and Saenphoom, P. (2014) Effects of asparagus trims by-product supplementation in laying hens diets on nutrient digestibility and productive performance. SU Sci. and Tech. J., 8(1): 74-82.

5. Viera-Alcaide, I., Hamdi, A., Rodríguez-Arcos, R., GuillénBejarano, R. and Jiménez-Araujo, A. (2020) Asparagus cultivation co-products: From waste to chance. J. Food Sci. Nutr., 6(1): 057.

6. Singh, R.S. and Singh, R.P. (2010) Production of fructooligosaccharides from inulin by endoinulinases and their prebiotic potentia. Food Technol. Biotechnol., 48(4): 435-450.

7. Huang, Q, Wei, Y., Lv, Y. and Hu, T. (2015) Effect of dietary inulin supplements on growth performance and intestinal immunological parameters of broiler chickens. Livest. Sci., 180: 172-176.

8. Rehman, A., Arif, M., Sajjad, N., Al-Ghadi, M.Q., Alagawany, M., Abd El-Hack, M.E., Alhimaidi, A.R., Elnesr, S.S., Almutairi, B.O., Amran, R.A., Hussein, E.O.S. and Swelum, A.A. (2020) Dietary effect of probiotics and prebiotics on broiler performance, carcass, and immunity. Poult. Sci., 99(12): 6946-6953.

9. Boguslawska-Tryk, M., Piotrowska, A. and Burlikowska, K. (2012) Dietary fructans and their potential beneficial influence on health and performance parameters in broiler chickens. J. Cent. Eur. Agric., 13(2): 272-291.

10. Shang, Y., Kumar, S., Thippareddi, H. and Kim, W.K. (2018) Effect of dietary fructooligosaccharide (FOS) supplementation on ileal microbiota in broiler chickens. Poult. Sci., 97(10): 3622-3634.

11. Sugiharto S. (2016) Role of nutraceuticals in gut health and growth performance of poultry. J. Saudi Soc. Agric. Sci., 15(2): 99-111.

12. Shang, Y., Regassa, A., Kim, J.H., and Kim, W.K. (2015) The effect of dietary fructooligosaccharide supplementation on growth performance, intestinal morphology, and immune responses in broiler chickens challenged with Salmonella Enteritidis lipopolysaccharides. Poult. Sci., 94(12): 2887-2897.

13. Zhao, Y., Li, J., Hao, W., Zhu, H., Liang, N., He, Z., Ma, K.Y. and Chen, Z.Y. (2017) Structure-specific effects of short-chain fatty acids on plasma cholesterol concentration in male Syrian hamsters. J. Agric. Food Chem., 65(50): 10984-10992.

14. Yang, G.Q., Yin, Y., Liu, H.Y. and Liu, G.H. (2016) Effects of dietary oligosaccharide supplementation on growth performance, concentrations of the major odor-causing compounds in excreta, and the cecal microflora of broilers. Poult. Sci., 95(10): 2342-2351.

15. Miremadi, F., Frank, M.A. and Stojanovska, S. (2014) Cholesterol reduction mechanisms and fatty acid composition of cellular membranes of probiotic Lactobacilli and Bifidobacteria. J. Funct. Foods., 9(1): 295-305.

16. Ooi, M.T. (2010) Cholesterol-lowering effects of probiotics and prebiotics: A review of in vivo and in vitro findings. Int. J. Mol. Sci., 11(6): 2499-2522.

17. Anandharaj, M., Sivasankari, B. and Rani, R.P. (2014) Effects of probiotics, prebiotics, and synbiotics on hypercholesterolemia: A review. Chin. J. Biol., 2014: 572754.

18. AOAC (2012) Official Method of Analysis Association of Analytical Chemists. $19^{\text {th }}$ ed. AOAC, Washington, DC. p121-130.

19. Reiffová, K. and Nemcová, R. (2006) Thin-layer chromatography analysis of fructooligosaccharides in biological samples. J. Chromatogr. A, 1110(1-2): 214-221.

20. National Research Council. (1994) Nutrient Requirements of Poultry. $9^{\text {th }}$ ed. National Academy Press, Washington, DC.

21. Fenton, T.W. and Fenton, M. (1979) An improved method for chromic oxide determination in feed and feces. Can. J. Anim. Sci., 59(3): 631-634.

22. Mountzouris, K.C., Tsirsikos, P., Palamidi, I., Arvanniti, A., Mohnl, M., Schatmayr, G. and Fegeros, K. (2010) Effect of probiotic inclusion level in broiler nutrition on growth performance, nutrient digestibility, plasma immunoglobulin, and cecal microflora composition. Poult. Sci., 89(1): 588-593.

23. Ghayour-Najafabadi, P., Khosravinia, H., Gheisari, A., Azarfar, A. and Khanahmadi, M. (2018) Productive performance, nutrient digestibility and intestinal morphometry in broiler chickens fed corn or wheat-based diets supplemented with bacterial or fungal-originated xylanase. Ital. J. Anim. Sci., 17(1): 165-174. 
24. Zewdie, A.K. (2019) The different methods of measuring feed digestibility: A review. EC Nutr., 14(1): 68-74.

25. Khattak, F., Paschalis, V., Green, M., Houdijk, J.G.M., Soultanas, P. and Mahdavi, J. (2018) TYPLEX® Chelate, a novel feed additive, inhibits Campylobacter jejuni biofilm formation and cecal colonization in broiler chickens. Poult. Sci., 97(4): 1391-1399.

26. Gava, M.S., Moraes, L.B., Carvalho, D., Chitolina, G.Z., Fallavena, L.C.B., Moraes, H.L.S., Herpich, J. and Salle, C.T.P. (2015) Determining the best sectioning method and intestinal segment for morphometric analysis in broilers. Braz. J. Poult. Sci., 17(2): 145-149.

27. McDonald, L.C., Hackney, C.R. and Ray, B. (1983) Enhanced recovery of injured Escherichia coli by compounds that degrade hydrogen peroxide or block its formation. Appl. Environ. Microbiol., 45(2): 360-365.

28. Horn, K.G., Gedris, C.A. and Rodney, K.M. (1996) Selective isolation of vancomycin-resistant enterococci. $J$. Clin. Microbiol., 34(4): 924-927.

29. Schillinger, U. and Holzapfel, W.H. (2003) Chapter 8 Culture media for lactic acid bacteria. Progr. Industr. Microbiol., 37: 127-140.

30. Cengiz, Ö., Köksal, B.H., Tatlı, O., Sevim, Ö., Ahsan, U., Üner, P.A. Ulutaş, A.G., Beyaz, D., Büyükyörük, S., Yakan, A. and Önol, A.G (2015) Effect of dietary probiotic and high stocking density on the performance, carcass yield, gut microflora, and stress indicators of broilers. Poult. Sci., 949(10): 2395-2403.

31. Walugembe, M., Hsieh, J.C.F., Koszewski, N.J., Lamont, S.J., Persia, M.E. and Rothschild, M.F. (2015) Effects of dietary fiber on cecal short-chain fatty acid and cecal microbiota of broiler and laying-hen chicks. Poult. Sci., 94(10): 2351-2359.

32. Tsirtsikos, P., Fegeros, K., Balaskas, C., Kominakis, A. and Mountzouris, K.M. (2012) Dietary probiotic inclusion level modulates intestinal mucin composition and mucosal morphology on broilers. Poult. Sci., 91(8): 1860-1868.

33. Sakamoto, K., Hirose, H., Onizuka, A., Hayashi, M., Futamura, N., Kawamura, Y. and Ezaki, T. (2000) Quantitative study of change in intestinal morphology and mucous jel on total parenteral nutrition in rats. J. Surg. Res., 94(2): 99-106.

34. Marcu, A., Opriş, I.V., Dumitrescu, G., Ciochină, L.P., Marcu, A., Nicula, M., Peț, I., Dronca, D., Kelciov, B. and Mariș, C. (2013) The influence of genetics on economic efficiency of broiler chickens growth. J. Anim. Sci. Biotechnol., 46(2): 339-346.

35. Barbosa, F.J.A., Almeida, M., Shimokomaki, M., Pinheiro, J. W., Silva, C.A., Michelan, F.T., Bueno, F.R. and Oba, A. (2017) Growth performance, carcass characteristics and meat quality of griller-type broilers of four genetic lines. Braz. J. Poult. Sci., 19(1): 109-114.

36. Ojediran, T.K., Fasola, M.O., Oladele, T.O., Onipede, T.L. and Emiola, I.A. (2017) Growth performance, flock uniformity and economic indices of broiler chickens fed low crude protein diets supplemented with lysine. Arch. Zootec., 66(256): 543-550.

37. Seifi, K., Torshizi, M.A.K., Rahimi, S. and Kazemifard, M. (2017) Efficiency of early, single-dose probiotic administration methods on performance, small intestinal morphology, blood biochemistry, and immune response of Japanese quail. Poult. Sci., 96(7): 2151-2158.

38. Dev, K., Mir, N.A., Biswas, A., Kannoujia, J., Begum, J., Kant, R. and Mandal, A. (2020) Dietary synbiotic supplementation improves the growth performance, body antioxidant pool, serum biochemistry, meat quality, and lipid oxidative stability in broiler chickens. Anim. Nutr., 6(3): 325-332.

39. Reisinger, N., Ganner, A., Masching, S., Schatzmayr, G. and Applegate, T.J. (2012) Efficacy of a yeast derivative on broiler performance, intestinal morphology and blood profile. Livest. Sci., 143(1): 195-200.

40. Faria, P.B., Bressan, M.C., De Souza, X.R., Rossato, L.V., Botega, L.M.G. and Da Gama, L.T. (2010) Carcass and parts yield of broilers reared under a semi-extensive system. Braz. J. Poult. Sci., 12(3): 153-159.

41. Petracci, M., Betti, M., Bianchi, M. and Cavani, C. (2004) Color variation and characterization of broiler breast meat during processing in Italy. Poult. Sci., 83(12): 2086-2092.

42. Pathare, P.B., Opara, U.L. and Al-Said, F.A. (2013) Colour measurement and analysis in fresh and processed foods: A review. Food Bioproc. Technol., 6(1): 36-60.

43. Lepage, G. and Roy, C.C. (1986) Direct transesterification of all classes of lipids in a one-step reaction. J. Lipid Res., 27(1): 114-120.

44. Zhai, W.S., Neuman, L., Latour, M.A. and Hester, P.Y. (2008) The effect of male and female supplementation of 1-carnitine on reproductive traits of white Leghorns. Poult. Sci., 87(6): 1171-1181.

45. He, L.W., Meng, Q.X., Li, D.Y., Zhang, Y.W. and Ren, L.P. (2015) Meat quality, oxidative stability and blood parameters from Graylag geese offered alternative fiber sources in growing period. Poult. Sci., 94(4): 750-757.

46. Loponte, R., Bovera, F., Piccolo, G., Gasco, L., Secci, G., Iaconisi V. and Parisi, G. (2019) Fatty acid profile of lipids and caeca volatile fatty acid production of broilers fed a full fat meal from Tenebrio molitor larvae. Ital. J. Anim. Sci., 18(1): 168-173.

47. Steel, R.G.D. and Torrie, J.H. (1992) Principles and Procedure Statistics. $2^{\text {nd }}$ ed. McGraw-Hill Book Co., Inc., Singapore.

48. R Core Team. (2018) R: A Language and Environment for Statistical Computing. R Foundation for Statistical Computing, Vienna. R Core Team, Austria. Available from: http:/www.R-project.org. Retrieved on 08-12-2019.

49. Markowiak, P. and Śliżewska, K. (2017) Effects of probiotics, prebiotics, and synbiotics on human health. Nutrients, 9(9): 1021

50. Ding, S., Yan, W., Ma, Y. and Fang, J. (2021) The impact of probiotics on gut health via alternation of immune status of monogastric animals. Anim Nutr., 7(1): 24-30.

51. Józefiak, D., Kaczmarek, S. and Rutkowski, A. (2008) A note on the effects of selected prebiotics on the performance and ileal microbiota of broiler chickens. J. Anim. Feed Sci., 17(3): 392-397.

52. Nabizadeh, A. (2012) The effect of inulin on broiler chicken intestinal microflora, gut morphology, and performance. $J$. Anim. Feed Sci., 21(4): 725-734.

53. Yun, W., Lee, D.H., Choi, Y.I., Kim, I.H. and Cho, J.H. (2017) Effects of supplementation of probiotics and prebiotics on growth performance, nutrient digestibility, organ weight, fecal microbiota, blood profile, and excreta noxious gas emissions in broilers. J. Appl. Poult. Res., 26(4): 584-592.

54. Meng, Q.W., Yan, L., Ao, X., Jang, J.D., Cho, J.H. and Kim, I.H. (2010) Effects of chitooligosaccharide supplementation on egg production, nutrient digestibility, egg quality and blood profiles in laying hens. Asian Australas. J. Anim. Sci., 23(1): 1476-1481.

55. Mac Farlane, G.T., Steed, H. and Mac Farlane, S. (2008) Bacterial metabolism and health-related effects of galacto-oligosaccharides and other prebiotics. J. Appl. Microbiol., 104(2): 305-344.

56. Everard, A., Belzer, C., Geurts, L., Ouwerkerk, J.P., Druart, C., Bindels, L.B., Guiot, Y., Derrien, M., Muccioli, G.G., Delzenne, N.M., de Vos, W.M. and Cani, P.D. (2013) Crosstalk between Akkermansia muciniphila and intestinal epithelium controls diet induced obesity. Proc. Natl. Acad. Sci. U. S. A., 110(22): 9066-9071.

57. Hornung, C., Poehlein, A., Haack, F.S., Schmidt, M., Dierking, K., Pohlen, A., Schulenburg, H., Blokesch, M., Plener, L., Jung, K., Bonge, A., Krohn-Molt, I., Utpatel, C., Timmermann, G., Spieck, E., Pommerening-Roser, A., Bode, E., Bode, H.B., Daniel, R., Schmeisser, C. and Streit, W.R. (2013) The Janthinobacterium sp. HH01 genome encodes a homologue of the $V$. cholerae CqsA and L. pneumophila LqsA autoinducer synthases. PLoS One, 8(2): e55045. 
58. Bushell, F.M.L., Tonner, P.D., Jabbari, S., Schmid, A.K. and Lund, P.A. (2019) Synergistic impacts of organic acids and $\mathrm{pH}$ on growth of Pseudomonas aeruginosa: A comparison of parametric and bayesian non-parametric methods to model growth. Front. Microbiol., 9: 3196.

59. Józefiak, D., Rutkowski, A. and Martin, S.A. (2004) Carbohydrate fermentation in the avian ceca: A review. Anim. Feed Sci. Technol., 113(1-4): 1-15.

60. Buclaw, M. (2016) The use of inulin in poultry feeding: A review. J. Anim. Physiol. Anim. Nutr., 100(6): 1015-1022.

61. Vieco-Saiz, N., Belguesmia, Y., Raspoet, R., Auclair, E., Gancel, F., Kempf, I. and Drider, D. (2019) Benefits and inputs from lactic acid bacteria and their bacteriocins as alternatives to antibiotic growth promoters during food-animal production. Front. Microbiol., 10: 57.

62. Ahmed, M.M.N., Ismail, Z.S.H. and Abdel-Wareth, A.A.A. (2018) Application of prebiotics as feed additives in poultry nutrition-a review. Egypt. Poult. Sci. J., 38(1): 207-222.

63. Csernus, B. and Czeglédi, L. (2020) Physiological, antimicrobial, intestine morphological, and immunological effects of fructooligosaccharides in pigs. Arch. Anim. Breed, 63(2): 325-335.

64. Choi, K.Y., Lee, T.K. and Sul, W.J. (2015) Metagenomic analysis of chicken gut microbiota for improving metabolism and health of chickens a review. Asian Australas. J. Anim. Sci., 28(9): 1217-1225.

65. Kim, G.B., Seo, Y.M., Kim, C.H. and Park, I.K. (2011) Effect of dietary prebiotic supplementation on the performance, intestinal microflora, and immune response of broilers. Poult. Sci., 90(1): 75-82.

66. Geier, M.S., Torok, V.A. and Allison, G.E.R. (2009) Indigestible carbohydrates alter the intestinal microbiota but do not influence the performance of broiler chickens. $J$. Appl. Microbiol., 106(5): 1540-1548.

67. Gaggìa, F., Mattarelli, P. and Biavati, B. (2010) Probiotics and prebiotics in animal feeding for safe food production. Int. J. Food Microbiol., 141(Suppl 1): S15-S28.

68. Callaway, T.R., Edrington, T.S., Anderson, R.C., Harvey, R.B., Genovese, K.J., Kennedy, C.N., Venn, D.W. and Nisbet, D.J. (2008) Probiotics, prebiotics and competitive exclusion for prophylaxis against bacterial disease. Anim. Health Res. Rev., 9(2): 217-225.

69. Munoz, M., Mosquera, A. and Almeciga-Diaz, C.O.F. (2012) Fructooligosaccharides metabolism and effect on bacteriocin production in Lactobacillus strains isolated from ensiled corn and molasses. Anaerobe, 18(3): 321-330.

70. Babu, U.S., Sommers, K., Harrison, L.M. and Balan, K.V. (2012) Effects of fructooligosaccharide-inulin on Salmonella-killing and inflammatory gene expression in chicken macrophages. Vet. Immunol. Immunopathol., 149(1-2): 92-96.

71. Pourabedin, M. and Zhao, X. (2015) Prebiotics and gut microbiota in chickens. FEMS Microbiol. Lett., 362(15): 1-8.

72. Alloui, M.N., Szczurek, W. and Świątkiewicz, S. (2013) The usefulness of prebiotics and probiotics in modern poultry nutrition: A review. Ann. Anim. Sci., 13(1): 17-32.

73. Eeckhaut, V., Van Immerseel, F. and Croubels, S.P. (2011) Butyrate production in phylogenetically diverse Firmicutes isolated from the chicken caecum. Microb. Biotechnol., 4(4): 503-512.

74. Sergeant, M.J., Constantinidou, C., Cogan, T.A., Bedford, M.R., Penn, C.W. and Pallen, M.J. (2014) Extensive microbial and functional diversity within the chicken cecal microbiome. PLoS One, 9(3): e91941.

75. Shang, H.M., Sue, H., Shen, S.J., Yao, X., Wu, B., Wang, L.N., Jiang, Y.Y. and Ding, G.D. (2015) Effects of dietary polysaccharides from the submerged fermentation concentrate of Hericium caput-medusae (Bull.:Fr.) Pers. on fat deposition in broilers. Livest. J. Argri. Food Sci., 95(2): 267-274.

76. Abdel-Hafeez, H.M., Elham, S.E.S., Samar, S.T., Ibrahim, M.I.Y. and Asmaa, S.A.A. (2017) Effects of probiotic, prebiotic, and synbiotic with and without feed restriction on performance, hematological indices and carcass characteristics of broiler chickens. Asian Australas. $J$. Anim Sci., 30(5): 672-682.

77. Guaragnia, A., Boiagob, M.M., Bottaric, N.B., Morschc, V.M., Lopesc, T.F. and Da Silvab, A.S. (2020) Feed supplementation with inulin on broiler performance and meat quality challenged with Clostridium perfringens: Infection and prebiotic impacts. Microb. Pathog., 139: 103889 .

78. World Health Organization. (2009) Fats and fatty acids in human nutrition. Proceedings of the joint FAO/WHO expert consultation. November 10-14, 2008. Geneva, Switzerland. Ann. Nutr. Metab., 55(1-3): 5-300.

79. Tavaniello, S., Maiorano, G., Stadnicka, K., Mucci, R., Bogucka, J. and Bednarczyk, M. (2018) Prebiotics offered to broiler chicken exert positive effect on meat quality traits irrespective of delivery route. Poult. Sci., 97(8): 2979-2987.

80. Selim, S., Hyssein, E. and Abou-Elkhair, R. (2018) Effect of Spirulina platensis as a feed additive on laying performance, egg quality and hepatoprotective activity of laying hens. Eur. Poult. Sci., 82: 1-14.

81. Sibel, C.D., Mikail, B., Zeynep, E., Akpinar, G.C., Altug, K. and Vesile, D. (2016) Performance, egg quality and serum parameters of Japanese quails fed diet supplemented with Spirulina platensis. Fresenius Environ. Bull., 25(12a): 5857-5862.

82. Aktimur, S.H., Suher, M., Darilmaz, D.O., Aktimur, R. and Ergül, E. (2017) Effects of probiotics, prebiotics and symbiotics on serum cholesterol levels. Clin. Surg., 2(1652): 1652.

83. Salaj, R., Štofilová, J., Šoltesová, A., Hertelyová, Z., Hijová, E., Bertková, I., Strojný, L., Kružliak, P. and Bomba, A. (2013) The effects of two Lactobacillus plantarum strains on rat lipid metabolism receiving a high fat diet. Sci. World J., 2013: 135142.

84. Lye, H.S., Rusul, G. and Liong, M.T. (2010) Mechanisms of cholesterol removal by lactobacilli under conditions that mimic the human gastrointestinal tract. Int. Dairy J., 20(3): 169-175.

85. Shehata, M.G., El-Sahn, M.A., El Sohaimy, S.A. and Youssef, M.M. (2019) Review article role and mechanisms lowering cholesterol by dietary of probiotics and prebiotics: A review. Res. J. Appl. Sci., 19(8): 737-746.

86. Begley, M., Hill, C. and Gahan, C.G.M. (2006) Bile salt hydrolase activity in probiotics. Appl. Environ. Microbiol., 72(3): 1729-1738.

87. Wang, J., Zhang, H., Chen, X., Chen, Y., Menghebilige and Bao, Q. (2012) Selection of potential probiotic lactobacilli for cholesterol-lowering properties and their effect on cholesterol metabolism in rats fed a high-lipid diet. Int. J. Dairy Sci., 95(4): 1645-1654.

88. Shang, H.M., Hu, T.M., Lu, Y.J. and Wu, H.X. (2010) Effects of inulin on performance, egg quality, gut microflora and serum and yolk cholesterol in laying hens. Br. Poult. Sci., 51(6): 791-796.

89. Tang, S.G.H., Sieo, C.C., Ramasamy, K., Saad, W.Z., Wong, H.K. and Ho, Y.W. (2017) Performance, biochemical and haematological responses, and relative organ weights of laying hens fed diets supplemented with prebiotic, probiotic and symbiotic. BMC Vet. Res., 13(1): 248.

90. Berggren, A.M., Nyman, E.M., Lundquist, I. and Björck, I.M.E. (1996) Influence of orally and rectally administered propionate on cholesterol and glucose metabolism in obese rats. Br. J. Nutr., 76(2): 287-294.

91. Mistry, R.H., Gu, F., Schols, H.A., Verkade, H.J. and Tietge, U.J.F. (2018) Efect of the prebiotic fiber inulin on cholesterol metabolism in wildtype mice. Sci. Rep., 8(1): 13238.

92. Kim, Y.A., Keogh, J.B. and Clifon, P.M. (2018) Probiotics, prebiotics, synbiotics and insulin sensitivity. Nutr. Res. Rev., 31(1): 35-51.

93. Kalavathy, R., Abdullah, N., Jalaludin, S., Wong, C.V.L. and Ho, Y.W. (2006) Effects of Lactobacillus feed supplementation on cholesterol, fat content and fatty acid composition 
of the liver, muscle and carcass of broiler chickens. Anim. Res., 55(1): 77-82.

94. Bonos, E., Christaki, E., Abrahim, A., Soultos, N. and Paneri, P.F. (2010) Effect of dietary supplementation of mannan oligosaccharides on hydrogen ion concentration of the digestive tract and microbial populations of the ceca of Japanese quail (Coturnix japonica). Turk. J. Vet. Anim. Sci., 35(4): 263-269.

95. Fukushima, M., Yamada, A., Endo, T. and Nakano, M. (1999) Effects of a mixture of organisms, Lactobacillus acidophilus or Streptococcus faecalis on 6-desaturase activity in the livers of rats fed a fat-and cholesterol-enriched diet. J. Nutr., 15(5): 373-378.

96. Abdulla, N.R., Sabow, A.B., Foo, H.L., Loh, T.C. and Zamri, A.M. (2018) Growth performance, fatty acid profile and lipid oxidative stability of breast muscle in chickens fed probiotics and antibiotics or their mixture. S. Afr. J. Anim. Sci., 48(6): 1082-1092.

97. Hossain, M.E., Kim, G.W., Lee, S.K. and Yang, C.J. (2012) Growth performance, meat yield, oxidative stability, and fatty acid composition of meat from broiler fed diets supplemented with a medicinal plant and probiotics. Asian Australas. $J$.
Anim. Sci., 25(8): 1159-1168.

98. Benamirouche, K., Baazize-Ammi, D., Hezil, N., Djezzar, R., Niar, A. and Guetarni, D. (2020) Effect of probiotics and Yucca schidigera extract supplementation on broiler meat quality. Acta Sci. Anim. Sci., 42(1): 1-9.

99. Rodrigues, D., Rocha-Santos, T.A.P., Gomes, A.M., Goodfellow, B.J. and Freitas, A.C. (2012) Lypolisis in probiotic and synbiotic cheese: The influence of probiotic bacteria, prebiotic compounds and ripening time on free fatty acid profiles. Food Chem., 131(4): 1414-1421.

100. Gomaa, E.Z. (2017) Effect of prebiotic substances on growth, fatty acid profile and probiotic characteristics of Lactobacillus brevis NM101-11. Microbiology, 86(5): 618-628.

101. Ross, G.R., Van Nieuwenhove, C.P. and Gonzalez, S.N. (2012) Fatty acid profile of pig meat after probiotic administration. J. Agric. Food Chem., 60(23): 5974-5978.

102. Salah., A.S., Ahmed-Farid, O.A. and El-Tarabany, M.S. (2019) Carcass yields, muscle amino acid and fatty acid profiles, and antioxidant indices of broilers supplemented with synbiotic and/or organic acids. J. Anim. Physiol. Anim. Nutr., 103(1): 41-52.

$* * * * * * * *$ 